\title{
Does Analytic Thinking Insulate Against Pro-Kremlin Disinformation? Evidence from Ukraine ${ }^{1}$
}

\author{
Forthcoming in Political Psychology
}

Aaron Erlich ${ }^{12 *}$, Calvin Garner ${ }^{3}$, Gordon Pennycook ${ }^{45}$, and David G. Rand ${ }^{67}$

\author{
${ }^{1}$ Department of Political Science, McGill University \\ ${ }^{2}$ Centre for the Study of Democratic Citizenship, McGill University \\ ${ }^{3}$ Department of Political Science, University of Washington \\ ${ }^{4}$ Hill/Levene Schools of Business, University of Regina \\ ${ }^{5}$ Department of Psychology, University of Regina \\ ${ }^{6}$ Department of Brain and Cognitive Sciences, Massachusetts Institute of Technology \\ ${ }^{7}$ Sloan School of Management, Massachusetts Institute of Technology
}

* Corresponding author. Aaron Erlich, Department of Political Science, McGill University, 855

Rue Sherbrooke Ouest, Leacock Bldg Rm 414, Montréal, QC H2T2A1, Canada. Email:

aaron.erlich@mcgill.ca

\footnotetext{
${ }^{1}$ The authors collected the data presented in this paper in collaboration with the National Democratic Institute (NDI), which funded the research. The analysis and conclusions contained here solely represent those of the authors.
} 


\begin{abstract}
Pro-Kremlin disinformation campaigns have long targeted Ukraine. We investigate susceptibility to this pro-Kremlin disinformation from a cognitive science perspective. Is greater analytic thinking associated with less belief in disinformation, as per classical theories of reasoning? Or does analytic thinking amplify motivated system 2 reasoning (or "cultural cognition"), such that analytic thinking is associated with more polarized beliefs (and thus more belief in pro-Kremlin disinformation among pro-Russia Ukrainians)? In online $(\mathrm{N}=1,974)$ and face-to-face representative $(\mathrm{N}=9,474)$ samples of Ukrainians, we find support for the classical reasoning account. Analytic thinking, as measured using the Cognitive Reflection Test, was associated with greater ability to discern truth from disinformation - even for Ukrainians who are strongly oriented towards Russia. We find similar, albeit weaker, results when operationalizing analytic thinking using the self-report Active Open-minded Thinking scale. These results demonstrate a similar pattern to prior work using American participants. Thus, the positive association between analytic thinking and the ability to discern truth versus falsehood generalizes to the qualitatively different information environment of post-communist Ukraine. Despite low trust in government and media, weak journalistic standards, and years of exposure to Russian disinformation, Ukrainians who engage in more analytic thinking are better able to tell truth from falsehood.
\end{abstract}

\title{
Running Header
}

Analytic Thinking and Pro-Kremlin Disinformation

\section{Keywords}

Disinformation; Analytic thinking; Ukraine; Cognitive reflection test; News media 


\section{Introduction}

Online influence operations are a major source of concern (Alizadeh et al., 2020) and a longstanding tactic is to create discord via targeted disinformation (Karlsen, 2016; Mahairas \& Dvilyanski, 2018; Shultz \& Godson, 1984). One prominent example of this comes from Russia and its allies' disinformation campaigns (Freelon \& Lokot, 2020; Gerber \& Zavisca, 2016; Jankowicz, 2020). Ukraine is a crucial target for Russia and its allies in the context of territorial conflict between the two countries (Khaldarova \& Pantti, 2016; Mejias \& Vokuev, 2017). Indeed, as of April 2021, 4,100 examples of pro-Kremlin disinformation out of 11,000 in an EU database specifically targeted Ukraine (EU Vs. Disinfo, 2021).

We investigate this issue through the lens of cognitive and social psychology. A key goal is to determine who is most likely to be susceptible to disinformation campaigns. If we can understand the characteristics of the individuals who are resistant to such campaigns, it may be possible to devise solutions that, at minimum, help identify particularly vulnerable groups and, potentially, even improve people's capacity to detect disinformation. This is the focus of the present investigation.

\section{Motivated System 2 reasoning vs. lazy thinking}

The influential theory of motivated system 2 reasoning (MS2R, also referred to as "cultural cognition") contends that people engage in motivated reasoning when faced with information that threatens their identities (Kahan et al., 2017). Accordingly, MS2R posits that motivated reasoning is facilitated by increased cognitive ability, such that people who are better at reasoning will be better at conforming information processing to their political identity (Kahan, 2013). Indeed, studies on climate change and gun control find that individual differences in analytic thinking ability are associated with increased political polarization (Kahan et al., 2012, 2017). Interestingly, however, the vast majority of this work is situated in the U.S. political context. 
While it is clear that individuals are more likely to believe ideologically consistent misinformation, there are alternative accounts that question the direct effect of ideological consistence on belief and argue instead that belief in misinformation is driven more by lazy thinking than motivated system 2 reasoning (Pennycook \& Rand, 2019, 2021). In support of this claim, Pennycook and Rand (2019) found that people who rely more on their intuitions (in lieu of engaging in effortful deliberation) - as indexed by performance on the Cognitive Reflection Test - are more likely to believe fake news regardless of whether it is consistent or inconsistent with their political ideology. This indicates that reasoning does not seem to consistently facilitate political polarization in the context of misinformation. Follow-up work has replicated this finding with different measures of analytic thinking disposition that do not involve numeracy, such as the Actively Open-minded Thinking scale (Bronstein et al., 2019), used experimental manipulations to establish causality by showing that engaging in reasoning reduces belief in false news regardless of the news' ideological concordance (Bago et al., 2020a), and reported that inducing reliance on emotion increases belief in false news (Martel et al., 2020).

In a review of 14 studies conducted with American subjects, Pennycook and Rand (2021) find that people are actually better able to discern between true and false news if it is consistent with their political ideology (although the effect of cognitive reflection is twice as large). There is an overall tendency for people to believe claims more if they are consistent with their ideology, which some have argued indicates that there is partisan bias in the identification of fake news (Batailler et al., 2021; Gawronski, 2021). However, the effect of ideological consistency is larger for true content than it is for false content. Thus, if fake news detection is defined as the ability to differentiate truth from falsehood, ideology concordance actually increases fake news detection. Furthermore, recent studies attempting to isolate the underlying factors relating to experimental studies of motivated system 2 reasoning have showed that politically-relevant factual beliefs (i.e. priors) - and not political identity per se - explain why individual differences in analytic thinking are sometimes associated with political polarization (in short, people who tend to be more analytic also rely more heavily on their prior beliefs when evaluating new information (Bago et al., 2020b; Tappin et al., 2021). Again, however, this research was conducted solely in the U.S. political context. 
Therefore, drawing on previous findings, we test several hypotheses with regards to whether Ukrainian respondents will behave similarly to American respondents when faced with pro-Kremlin disinformation.

H1. Cognitive reflection will be associated with lower levels of belief in pro-Kremlin disinformation.

H2. Cognitive reflection will be associated with higher levels of belief in true stories.

Furthermore, we also examine whether reasoning appears to operate similarly among those who may be motivated to believe pro-Kremlin disinformation.

H3. Cognitive reflection will be associated with lower levels of belief in pro-Kremlin disinformation, irrespective of respondents' orientation towards Russia.

H4. Cognitive reflection will be associated with higher levels of belief in true stories, irrespective of respondents' orientation towards Russia.

\section{The Soviet Successor States as an Important Case}

\section{A different context for cognitive reflection?}

Ukraine represents a new and fascinating context in which to study the relationship between analytic thinking, political ideology, and belief in not just misinformation but disinformation. Ukraine represents a uniquely troubled domestic information space due to the sheer volume of disinformation attacks from Russia. These challenges in Ukraine's information space make it qualitatively different from Western democracies where misinformation tends to be less organized and is more likely to be domestic (Helmus et al., 2018; Munger, 2020). This dynamic could impact the underlying influence of ideology and cognitive reflection in predicting belief in misinformation in a few ways.

First, Ukraine's legacy as a post-communist country could affect the relationship that we study in ways that are at odds with patterns found in consolidated democracies. Under communism, media outlets were entirely subservient to state propaganda efforts, and the government used the media to maintain its hold on power through aggressive manipulation of the information space (McNair, 2006). Partially as a result of this legacy, post- 
communist societies have low trust levels in the state and media institutions (McKee et al., 2013). This pattern holds in Ukraine, where more education correlates with less trust (Johnson, 2005, p. 76).

Second, since the fall of the Soviet Union, Ukraine has struggled with a weak media market, where ownership is highly concentrated and politically connected, and journalistic standards are low (Ryabinska, 2011). Behaviors such as paying for favorable news coverage are rife. Moreover, media owners actively intervene in the editorial and news coverage of the outlets they own to support their political patrons. As a result, individuals have good reason to be skeptical of any information they receive and possibly feel that it is too difficult to tell facts from fiction.

Third, as noted, Russia and its allies have been waging an intense and sustained information war in Ukraine for many years. This campaign accelerated in the wake of the Maidan protest movement that led to the ouster of Ukrainian President Viktor Yanukovych in 2014, who was closely aligned with the Kremlin. While some aspects of Russia's recent disinformation campaigns appear to be aimed at particular policy ends (Abrams, 2016; Kragh \& Åsberg, 2017), in other respects, the goal of the Russian government seems to be confusion for its own sake, in line with findings on Chinese government disinformation strategies (King et al., 2013). The objective, then, "is not to convince or persuade, but to keep the viewer hooked and distracted, passive and paranoid, rather than agitated to action" (Pomerantsev \& Weiss, 2014, p. 11). According to some accounts, these efforts have been highly successful, especially online, where it has become "impossible" to tell the truth from disinformation (Abrams, 2016, p. 21).

While cognitive reflection is associated with a greater ability to discern truth from disinformation in the context of developed democracies with traditionally healthier information environments, this relationship may not hold everywhere. Indeed, there is ample reason to think that Ukraine's media environment, which faces severe challenges due to historical legacy, contemporary problems, and external attack, could eliminate or even reverse the relationship between cognitive reflection and belief in disinformation. In contrast, political ideology (in the 
form of a pro-Russian stance) is a salient potential factor. Hence, Ukraine makes a challenging case to test the relationship between reasoning and the ability to see through disinformation.

\section{Method}

\section{Participants}

To examine Ukrainian citizens' beliefs in both pro-Kremlin disinformation and verifiable true news stories we use data from two studies commissioned by the National Democratic Institute. Infosapiens, a Ukraine-based research firm, implemented the first study. While online panels are relatively new in Ukraine, survey firms have taken extensive steps towards creating relatively large subject pools from which they can sample for online studies. Infosapiens online panel contained more than 30,000 active participants at the time of the research. The pilot study ran between March 4-5, and fieldwork was carried out between March 11-March 14, 2019, and included 1,974 respondents.

The second study, implemented by the Kyiv Institute of International Sociology (KIIS), included a large sample $(9,474$ respondents $){ }^{2}$ The face-to-face, nationally representative study was carried out between September 18 and October 31, 2019. We control for unequal sampling probabilities in later regression modeling. In both studies, respondents could choose whether they wanted to participate in the study in Russian or Ukrainian, and all materials were translated into both languages. The Online Appendix contains descriptive statistics on our sample.

\section{Materials}

\footnotetext{
2 The sample size was so large, so to include several large oversamples of specific regions of Ukraine, which led to unequal probabilities of selection.
} 
We pre-registered all of our measures for both studies with AsPredicted.org. We note when there are deviations from this analysis plan in the body of the text. Preregistrations, data, and the online supporting information are all available on PsyArxiv. ${ }^{3}$ Ethical approval was obtained by the first author.

\section{Measures of Motivation to Believe Russian Disinformation}

Who in the Ukrainian context will be more likely to believe pro-Kremlin disinformation news stories because of motivated reasoning? First, we argue that those Ukrainians who support political forces who are pro-Russia will be more likely to believe untrue Russian news stories, a topic we address in further detail in a companion paper (Erlich \& Garner, 2021b). We build on a critical distinction in Ukrainian politics between pro-Russian and proEuropean political parties (Noutcheva, 2018, p. 323). ${ }^{4}$ Pro-Russia voters and the parties they support are noteworthy because they maintain a more favorable view towards relations with Russia than other parties do. Given that they support closer relations with Russia, those who support these parties should be more motivated to believe Russian disinformation.

In recent years, as in other European countries, though relatively small, a variety of xenophobic, hard-right political parties have also emerged in Ukraine (Shekhovtsov, 2011; Shekhovtsov \& Umland, 2014). These parties do not neatly fit into the pro-EU or pro-Russia categorization. Therefore, we add a third category of voters who support hard-right parties. We classify voters as belonging to one of three mutually exclusive categories: proRussia party supporters (1), pro-EU party supporters (-1), or far-right nationalist party supporters (0). We do so based on a traditional question that asks respondents which party they feel is closest to them. A complete classification of Ukraine's various political parties can be found in the preregistration for Study 1 . As an alternative measurement, In Study 2, we focus on the extent to which individuals view Russia as a threat. To do so, we pose two questions: 1) the extent to which respondents think Russian is a threat on a three-point scale (no

\footnotetext{
${ }^{3}$ https://psyarxiv.com/4yrdj/.

${ }^{4}$ Importantly, we do not assume that these voters want to integrate with Russia or have irredentist claims, just that they support parties who remind voters of Ukraine's long-standing cultural and political ties to Russia, even if they may also sometimes support Europe. Abdelal (2005, p. 116) refers to these parties and their voters as "not anti-Russian."
} 
threat at all, some threat, big threat) and the extent to which respondents think U.S./European values are a threat. We take the standardized differences between these two answers as our measurement of Russian threat.

Orientation towards Russian may be another vector associated with motivated reasoning. The role that language and ethnic identity at play in Ukraine has been the subject of intense recent scholarship (Erlich \& Garner, 2021a; Frye, 2010; Kulyk, 2011, 2018, 2019; Onuch \& Hale, 2018). Of course, Russian-languages speakers and those who see themselves as ethnic Russian can feel intensely pro-Ukrainian. Many Ukrainians believe in an inclusive civic national identity in Ukraine (Kulyk, 2016; Shevel, 2002). However, it may be that those who have a stronger ethnic or linguistic connection to Russia may be more motivated to believe untrue stories emanating from Russia. They may also access media from Russia more often, and there is evidence that this media influences them (Peisakhin \& Rozenas, 2018).

In both studies, we create an additive index of Russian ethnolinguistic identity where we measure language in which the survey was taken, stated native language, stated language spoken at work, stated language spoken at home, and stated ethnic identity. For each element where respondents choose only Russian, they get a +1 , for each element, respondents choose only Ukrainian, they get a -1 . Respondents, therefore, can vary from -5 (See themselves as only ethnic Ukrainian, whose native language is Ukrainian, took the survey in Ukrainian and speaks Ukrainian at work and at home +5 (Sees themselves as only ethnic Russian, and does everything linguistically in Russian). ${ }^{5}$

\section{Measures of Analytic Thinking and Cognitive Reflection.}

In Study 1, we adapted a 7-item Cognitive Reflection Test (CRT) to assess individual differences in analytic thinking. We used the original three items from Frederick (2005) (with slight changes, Shenhav et al., 2012; see the online appendix) and four non-numeric items from Thomson and Oppenheimer (2016). Study 2 uses the four non-numeric items because of their better performance in Study 1 (see Online Appendix). Each CRT problem

\footnotetext{
${ }^{5}$ We stated four measures in the pre-registration. We included the behavior measure to make five.
} 
cues an intuitive but incorrect answer. For example, "If you're running a race and you pass the person in second place, what place are you in?" The intuitive answer is "first place," but the correct answer is "second place." In Study 1, participants were also given two versions of the Actively Open-minded Thinking (AOT) scale, which included seven items from Haran, Ritov, \& Mellers (2013) and an additional 17 items from the original full AOT scale (Stanovich \& West, 1997). In Study 2, because of study length, participants were given a battery of the first six AOT questions of the 17 questions from the Stanovich and West battery used in Study $1 .{ }^{6}$

\section{Disinformation narrative identification and assignment}

To test the relationship between cognitive reasoning and belief in disinformation, we needed to identify many relevant stories that Ukrainian respondents might plausibly believe. To identify these stories, we leverage the website EU vs. Disinfo (EUD), part of the European Union's efforts to track and respond to pro-Kremlin disinformation. EUD publishes and de-bunks pro-Kremlin messaging, including messaging that targets Ukraine. Examples of stories identified by EUD include headlines such as, "NATO soldiers are fighting in the east of Ukraine," "Ukraine will have to cancel pensions to comply with IMF requirements for reserve funds," and "Ukrainian armed forces are firing on their own positions in order to pin it on separatists."

Prior work indicates that the strategic goals of Soviet and Russian disinformation campaigns frequently include creating wedges between domestic groups and enhancing Russia's image among those who might be favorable to its perspective (Xia et al., 2019). We sought to ensure that headlines chosen for our study had a reasonable degree of variation with respect to the types of disinformation to which Ukrainians are exposed. Based on this prior literature, we conceptualize three strategies for disinformation headlines: undermining the Ukrainian state and government; driving a wedge between Ukraine and its allies in the West (EU and NATO member countries); and promoting a positive view of Russia. We also sought to ensure that the headlines we chose covered four broadly defined subjects: politics and government; the economy; the military; and culture, identity, or historical

\footnotetext{
${ }^{6}$ For the main linear models, in the paper, we present unstandardized versions. For the multi-level models, we present in the Appendix, these are standardized. Summary statistics are also provided in the Online Appendix.
} 
memory. ${ }^{7}$ In addition to disinformation headlines on each subject for each strategy, we also included a true headline for each subject-strategy combination to serve as a baseline measure. Thus, we had 16 different cells subject-strategy combinations ( 3 disinformation strategies plus true headlines $\times 4$ subjects).

Two co-authors then reviewed EUD headlines and selected between four and six headlines for each strategysubject cell in consultation with partners in Ukraine. We then also worked with our research partners in Ukraine to validate these headlines and translate each back into Russian and Ukrainian, the two languages in which respondents could elect to take the survey (EUD had translated them into English out of whichever language they were originally written). We also consulted with our Ukrainian partners to identify four true headlines for each subject. The first wave of online data collection contained 98 individual headlines, and the second wave of data collection had 48 headlines. ${ }^{8}$ The online Appendix contains sample headlines.

Our primary outcome variable of interest in both studies is the perceived accuracy of the headlines that each individual receives (randomized from the full set). ${ }^{9}$ This measurement strategy is similar to other studies on the topic (Clayton et al., 2019; Kuru et al., 2017; Pennycook et al., 2018). The scale is a six-point scale in Study 1 and a seven-point scale in Study 2.

\section{Estimation}

To examine our main question of interest along with our pre-registered measures, we pre-registered a series of regression models with perceived accuracy as the dependent variable (one observation per rating, 16 observations per subject). Specifically, we pre-registered four main models with independent variables that include: headline

\footnotetext{
${ }^{7}$ Three of these four subjects we identified in an earlier literature on Soviet disinformation (Meiselman et al., 1987), and the fourth (historical) emerged from our review, but is also well-documented https://www.zotero.org/google-docs/?0ahZZH (Koposov, 2017).

${ }^{8}$ We had to limit the number of stories, given the complexity of face-to-face enumeration.

${ }^{9}$ In Study 1 respondent received 16 statements (one for each cell). In Study2, they received 18, as they were randomly assigned to receive all the stories from one cell.
} 
veracity $(0=$ false, $1=$ true), subject cognitive style (one of two possible measurements), subject orientation towards Russia (one of two possible measurements), and all their interactions.

We also specified a series of robustness checks. First, in Study 1 we stated that we would disaggregate the numerical and non-numerical CRT score and also disaggregate the short and long AOT scores. ${ }^{10}$ We also specified that we would control for age, gender, education, and income in a separate set of regression specifications and control for sample strata fixed effects in Study 2. We also stated we would examine the relationship between our outcome variable and our 16 topic-strategy combinations.

The four models vary in their definition of cognitive style and ideological concordance, and these variables also vary between Study 1 and Study 2. We document these details in Table 1.

Table 1

\begin{tabular}{|c|c|c|c|}
\hline Variable & Study 1 & Study 2 & Robustness Checks \\
\hline \multirow[t]{3}{*}{ Cognitive Style } & 7-item CRT & 4-item CRT & $\begin{array}{l}\text { Numerical vs. non- } \\
\text { numerical CRT } \\
\text { results (Study 1) }\end{array}$ \\
\hline & AOT 24-item & AOT 6-item & $\begin{array}{l}\text { Short v. Long AOT } \\
\text { (Study 1) }\end{array}$ \\
\hline & & & $\begin{array}{l}\text { The aggregate of } \\
\text { CRT and AOT }\end{array}$ \\
\hline $\begin{array}{l}\text { Russian } \\
\text { ethnolinguistic } \\
\text { orientation }\end{array}$ & $\begin{array}{l}\text { 10-point scale of } \\
\text { language and ethnic } \\
\text { identity }\end{array}$ & $\begin{array}{l}\text { 10-point scale of } \\
\text { language and ethnic } \\
\text { identity }\end{array}$ & \\
\hline $\begin{array}{l}\text { Russian ideological } \\
\text { orientation }\end{array}$ & $\begin{array}{l}\text { 3-point Party } \\
\text { Affiliation (Pro- } \\
\text { Russia -1 Far-Right 0, } \\
\text { Pro-Europe 1) }\end{array}$ & $\begin{array}{l}\text { Russian threat } \\
\text { difference of two 3- } \\
\text { point scales (six-point } \\
\text { scale) }\end{array}$ & \\
\hline
\end{tabular}
${ }^{10}$ We also provide a third robustness check in Online Appendix, which aggregates the AOT and CRT scores. This was not pre-
registered. 
In each case, we specified that we would use multilevel mixed-effects models with varying intercepts by subject and statement and varying respondent-slopes on whether the story was true and varying narrative-slopes and cognitive style and Russian orientation and their interaction. If the full models did not converge, we specified we would attempt varying intercepts only. If those models still did not converge, we specified we would use linear regression with robust standard errors clustered on subject and statement.

\section{Results}

We ran all the models specified in the pre-registration. For the models, the coefficients on our main variables of interest (the story veracity, Russian ethnolinguistic orientation, cognitive style, and ideological concordance), the results are substantively and statistically similar when using either CRT or AOT (in Study 1) to operationalize cognitive style. However, there is more variation across models when using AOT to operationalize cognitive style (perhaps because of the abridged version in the second study). With the multilevel models, we obtained only mixed success in model convergence. Therefore, per our pre-registration, we present results from the linear regression models with clustered standard errors but provide the tables for the multilevel models and the convergence status in the Online Appendix. The multilevel results are very similar to the ones we present in the body of the paper.

In both Study 1 and Study 2, as shown in Tables 2 and 3, we find strong evidence that cognitive reflection is associated with an increased ability to distinguish true stories from pro-Kremlin disinformation, in line with $\mathrm{H} 1$ and $\mathrm{H} 2 .{ }^{11}$ In both studies, as CRT scores increase, in most models, respondents are statistically more likely to correctly perceive disinformation stories as false. Cognitive reflection has a particularly strong correlation with being able to identify true stories as true, and this coefficient is always significant at traditional levels $p<.05$.

\footnotetext{
${ }^{11}$ Table 2 presents results without demographic controls. Models with nearly identical results, which include demographic controls are included in the Online Appendix.
} 
The same holds for the AOT in Study 1, but not in Study 2. We believe this could be driven by the shortness of the battery in Study 2.

We also generally find support for $\mathrm{H} 3$ and $\mathrm{H} 4$ in most of our measurements. That is, we find that cognitive style is associated with an increased ability to distinguish true stories from disinformation stories even for those respondents who are strongly oriented towards Russia. That being said, the relationship between analytic reasoning and attenuated belief in pro-Kremlin disinformation appears to be less strong amongst those that are politically oriented towards Russia in Study 1 when we use our CRT measurement. Nevertheless, analytic thinking is positively correlated with belief in true stories similarly across the political spectrum.

Table 2: Linear regressions models from Study 1

Study 1: Linear Models - Dependent variable: belief

Constant

True

CRT

AOT

Russian Orientation

Russia Pol. Orientation

CRT $\times$ True

AOT $\times$ True

CRT $\times$ RussianOrientation

AOT $\times$ RussianOrientation

True $\times$ RussianOrientation

CRT $\times$ True $\times$ RussianOrientation

AOT $\times$ True $\times$ RussianOrientation

CRT $\times$ Pro Russia Pol. Orientation

AOT $\times$ Pro Russia Pol. Orientation

True $\times$ Pro Russia Pol. Orientation

CRT $\times$ True $\times$ Pro Russia Pol. Orientation

AOT $\times$ True $\times$ Pro Russia Pol. Orientation
Model 1 Model 2 Model 3 Model 4

$2.713 * * * 2.887 * * * 2.661 * * * 2.980 * * *$

$\begin{array}{llll}(0.075) & (0.118) & (0.076) & (0.133)\end{array}$

$\begin{array}{llll}1.162 * * * & 0.790 * * * & 1.219 * * * & 0.663 * *\end{array}$

$\begin{array}{llll}(0.163) & (0.210) \quad(0.163) & (0.238)\end{array}$

$-0.306 * * * \quad-0.120$

(0.075)

$-0.652 * *$

(0.210)

$0.115^{* * *} 0.155^{* * *}$

$(0.012) \quad(0.028)$

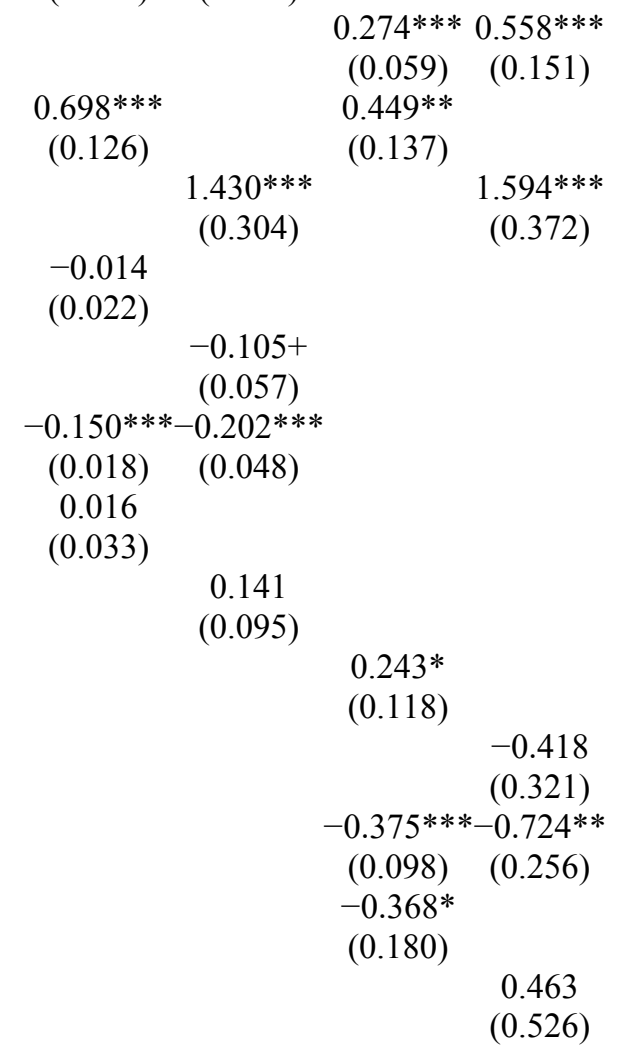


Study 1: Linear Models - Dependent variable: belief

Model 1 Model 2 Model 3 Model 4

Observations

32,640

32,640

$32,640 \quad 32,640$

Adjusted R $\mathbf{2}^{2}$

0.217

0.216

$0.193 \quad 0.193$

$+\mathrm{p}<0.1, * \mathrm{p}<0.05, * * \mathrm{p}<0.01, * * * \mathrm{p}<0.001$

Two-way standard errors clustered on Respondent and Narrative

Table 3: Linear regression models from Study 2

Study 2: Linear Models - Dependent variable: belief

Constant

True

Model 1 Model 2 Model 3 Model 4

CRT

$-0.535 * * *-0.533 * * *-0.690 * * *-0.715 * * *$

$\begin{array}{llll}(0.123) \quad(0.136) & (0.121) \quad(0.134)\end{array}$

$0.635 * * \quad 0.713 * \quad 0.713 * * \quad 0.940 * *$

$\begin{array}{llll}(0.243) & (0.317) \quad(0.227) \quad(0.290)\end{array}$

AOT

$-0.294 * * *$

$-0.208 * * *$

(0.049)

(0.045)

Russian Orientation

$0.146 * * * 0.213 * * *$

$-0.331 * * \quad-0.178+$

Russian Orientation

(0.016) (0.026)

Russia Not A Threat
$0.599 * * *$
$(0.031) \quad(0.044)$
(0.071)
$(0.031)$
$0.436 * * *$
(0.044)

CRT $\times$ True

AOT $\times$ True

CRT $\times$ RussianOrientation

$-0.020$

(0.018)

AOT $\times$ RussianOrientation
$-0.129 * *$
(0.040)
$-0.204 * * *-0.331 * * *$
$(0.037) \quad(0.063)$
0.040
(0.033)
$0.243 * *$

True $\times$ RussianOrientation

CRT $\times$ True $\times$ RussianOrientation

AOT $\times$ True $\times$ RussianOrientation

(0.091)

CRT $\times$ Russia Not A Threat

(0.033)

AOT $\times$ Russia Not A Threat

$$
\begin{array}{rc} 
& -0.174 * \\
& (0.068) \\
-0.410 * * *-0.579 * * * \\
(0.067) \quad(0.109) \\
-0.179 * * *
\end{array}
$$

True $\times$ Russia Not A Threat

CRT $\times$ True $\times$ Russia Not A Threat

AOT $\times$ True $\times$ Russia Not A Threat

0.132

\begin{tabular}{lcccc}
\hline Oblast Strata Fixed Effects & Yes & Yes & Yes & Yes \\
\hline Observations & 163,727 & 108,609 & 122,638 & 89,511 \\
Adjusted R $^{2}$ & 0.094 & 0.093 & 0.115 & 0.111 \\
\hline
\end{tabular}

$+\mathrm{p}<0.1, * \mathrm{p}<0.05, * * \mathrm{p}<0.01, * * * \mathrm{p}<0.001$

Two-way standard errors clustered on Respondent and Narrative 
Figures 1 and 2 graphically show the results from the models. ${ }^{12}$ These figures show the predicted level of belief for individuals while varying whether the story was true or false, levels of CRT and ideological orientation. The figures also show the midpoint of the scale (3.5 in Study 1 and 4 in Study 2). We focus here on our CRT measures in more detail. For the Russian Orientation we compare individuals in first, median and third quartiles. These correspond to $-4,-1$, and 2 in Study 1 and $-3,-1$, and 1 in Study $2 .{ }^{13}$ On average, respondents, regardless of level of CRT or positionality towards Russia, rate disinformation stories as false. For example, those respondents who have the first quartile of Russian ethnolinguistic orientation (-4) and the lowest levels of CRT (0), on average rate a disinformation stories as a 2.2 ("false") in Study 1 and 2.25 ("false") in Study 2, those who have a high Russian ethnolinguistic orientation (2) and low CRT (0) also rate the disinformation stories as false, but just barely so (2.9 in Study 1 and 3.8 in Study 2). Across both studies individuals demonstrate higher levels of disbelief in pro-Kremlin disinformation when the have higher CRT scores. For example, those who are in the third quartile of our Russian ethnolinguistic measure (highly Russia-oriented) who have high CRT scores (1), on average have beliefs in disinformation stories that are .33 points lower in Study 1 and .31 points lower in Study 2 compare to their similarly highly Russian-oriented counterparts who have low CRT scores (0).

Across both studies, as CRT increases, those across the Russian orientation spectrum also increase their belief in true stories at similar rates. For true stories, at all levels of Russian Orientation individuals rate true stories as true, although those with higher levels of Russian orientation and low levels of CRT are not statistically distinguishable from an indeterminate rating and are just

\footnotetext{
${ }^{12}$ Study 1 differs from Study 2 in that it controls for design-based strata in the nationally representative study across all models.

${ }^{13}$ The negative median reflects the fact that the majority of Ukrainian society is more ethnolinguistically Ukrainianoriented per our measurement strategy. This measurement is in line with recent survey data (Onuch \& Hale, 2018).
} 
barely so in Study 2. However, those with high levels of CRT, on average are much more able to distinguish True stories as true. For example, high Russian oriented individuals ( $3^{\text {rd }}$ quartile) with the highest CRT of 1, on average, rates true stories as 4.2 and 4.4 in the two studies, while a high Russian-oriented individual with a CRT score of 0 rates a true story as 3.8 and $4-$ a .4-point difference respectively for the two studies.

While a similar correlation pattern to the one we observe with our measure of Russian Orientation exists between our measure of Russian Threat and CRT and whether the story is true in Study 2, the pattern does not exist for our measurement of Russian Political Orientation in Study 1. That is, in Study 1, those that are politically-oriented towards Russia are more likely to rate true stories as true, but they are not more likely to rate disinformation stories as false, while those who support anti-Russia parties are. However, our AOT shows the same relationship in terms of Russian political orientation as our other two measurements. Why the relationship is strong with our AOT measurement but not with our CRT measurement is a question for further study. ${ }^{14}$

Robustness checks show that our findings are not driven by any topic of the news story or strategy. We show the zero-order correlations between strategy and topic and our measures of the AOT and CRT in the Online Appendix. In the Online Appendix, we also run regressions with fixed effects for these topics and strategies and results are broadly similar to the models without these effects. Furthermore, in Study 1, we show that the non-numeric CRT has a stronger relationship with

\footnotetext{
${ }^{14}$ We note that in Study 1 the correlation between the CRT and AOT (.21) is similar to correlations found in the United States (Pennycook et al., 2020). However, CRT-AOT correlation in Study 2 is weaker (.10). See Online Appendix Tables 11 and 13.
} 
misinformation than the numeric one, perhaps reiterating the need for non-numeric versions of this scale. 

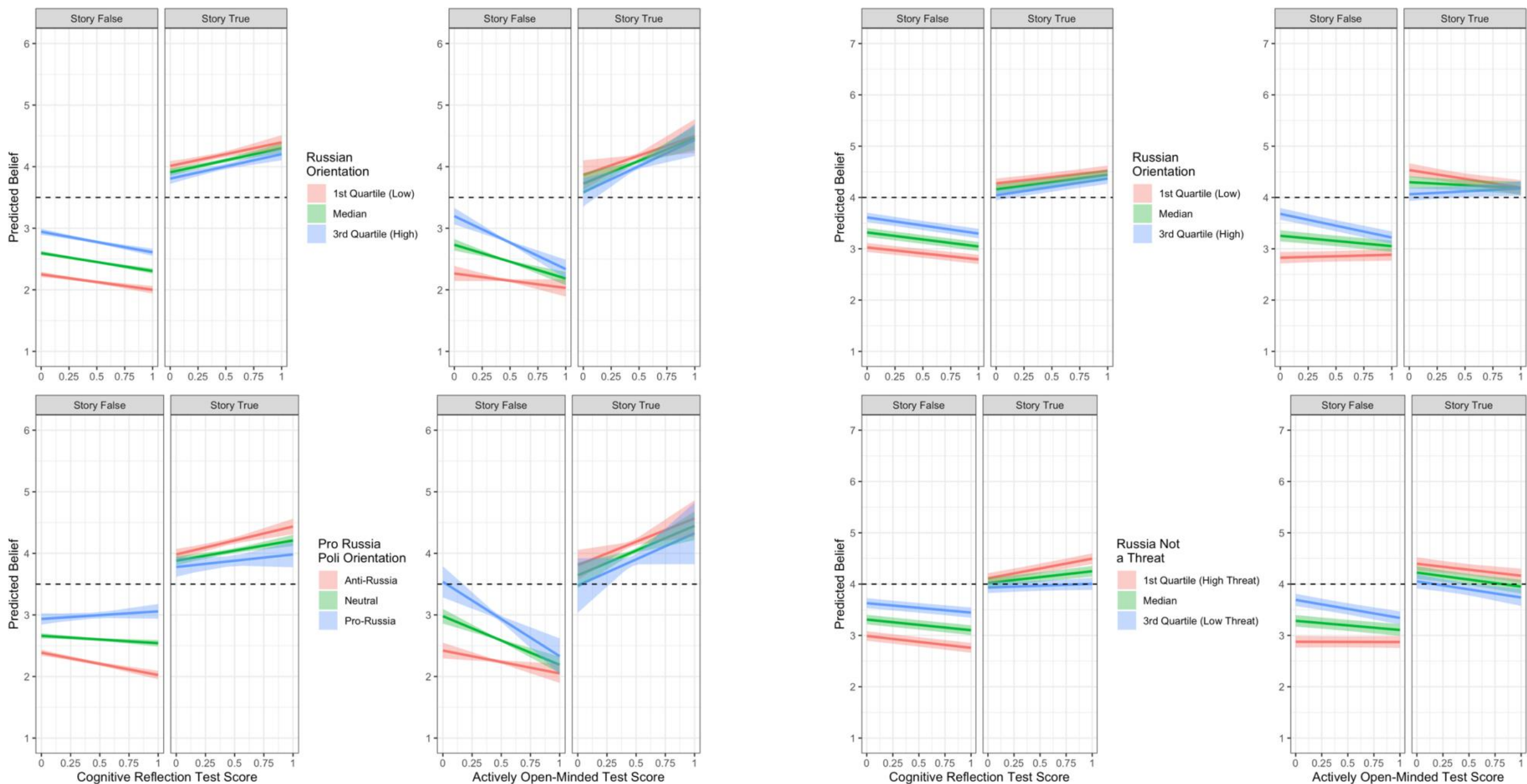

Figure 1: Predicted belief across varying levels of CRT and AOT in Study 1


Figure 2: Predicted belief across varying levels of CRT and AOT in Study 2 


\section{Discussion}

In summary, this paper provides an important contribution to the literature on the political psychology of misinformation. We find evidence that individuals who engage in analytic thinking are more likely to rate false stories as false and trues stories as true. Furthermore, this was evident regardless of one's political stance on Russia (and, therefore, the ideological consistency of the news content). This constitutes strong evidence for the role of analytic thinking in curtailing belief in misinformation because Ukraine represents an environment that has a long history of fabricated news and has been inundated by pro-Kremlin disinformation in recent years. Indeed, the fact that Ukrainian citizens can still distinguish pro-Kremlin disinformation for truth-oriented news speaks to the optimism we should have about further improving the information environment in countries such as Ukraine.

This research also builds on a growing body of research that questions the motivated system 2 account of information processing. We failed to find evidence that people who are better (or more likely to) engage in effortful deliberation are more politically polarized across a large number of news headlines $(\mathrm{N}=146)$ and two very large samples (total $\mathrm{N}=11,448)$. Furthermore, while there was a general tendency for people with a Pro-Russian orientation to have higher belief in proKremlin disinformation and to disbelieve true stories more than other Ukrainians, this association is not necessarily the result of motivated reasoning (Tappin et al., 2020). It is possible, for example, that the overall correlation between ideology and belief is driven by exposure to similar claims in the past (Pennycook et al., 2018). 
Our study has some important limitations. Future research could look more closely at the relationship between different elements of Russian orientation. We examined identity, political ideology and attitudinal-based measures of Russian orientation. While all three measures show the same types of correlations with belief in pro-Kremlin disinformation (albeit to different degrees), we are not able to disentangle these three measurements. Further work could focus on research designs that try to match respondents across these dimensions to better understand these dynamics. Additionally, while we used two different measures of thinking style, we did not measure political knowledge or general intelligence. Thus, we do not know whether the relationships we observed with CRT and AOT are robust to controlling for these factors, or if our findings could be explained by political knowledge and/or general intelligence rather than thinking style. Future work should investigate this possibility. Overall, our study is a call for more cross-cultural work in political psychology.

\section{References}

Abdelal, R. (2005). National Purpose in the World Economy: Post-Soviet States in Comparative Perspective (Vol. 1-1 online resource (xi, 221 pages).). Cornell University Press.

Abrams, S. (2016). Beyond Propaganda: Soviet Active Measures in Putin's Russia. Connections, 15(1), 5-31. https://www.jstor.org/stable/26326426

Alizadeh, M., Shapiro, J. N., Buntain, C., \& Tucker, J. A. (2020). Content-based features predict social media influence operations. Science Advances, 6(30), eabb5824. https://doi.org/10.1126/sciadv.abb5824

Bago, B., Rand, D. G., \& Pennycook, G. (2020a). Fake news, fast and slow: Deliberation reduces belief in false (but not true) news headlines. Journal of Experimental Psychology: General, 149(8), 1608-1613. https://doi.org/10.1037/xge0000729

Bago, B., Rand, D., \& Pennycook, G. (2020b). Reasoning about climate change. PsyArXiv. https://doi.org/10.31234/osf.io/vcpkb

Batailler, C., Brannon, S. M., Teas, P. E., \& Gawronski, B. (2021). A Signal Detection Approach to Understanding the Identification of Fake News. Perspectives on Psychological Science, 22. 
Bronstein, M. V., Pennycook, G., Bear, A., Rand, D. G., \& Cannon, T. D. (2019). Belief in Fake News is Associated with Delusionality, Dogmatism, Religious Fundamentalism, and Reduced Analytic Thinking. Journal of Applied Research in Memory and Cognition, 8(1), 108-117. https://doi.org/10.1016/j.jarmac.2018.09.005

Clayton, K., Davis, J., Hinckley, K., \& Horiuchi, Y. (2019). Partisan motivated reasoning and misinformation in the media: Is news from ideologically uncongenial sources more suspicious? Japanese Journal of Political Science, 20(3), 129-142. https://doi.org/10.1017/S1468109919000082

Erlich, A., \& Garner, C. (2021a). Subgroup Differences in Implicit Associations and Explicit Attitudes during Wartime. International Studies Quarterly, sqab005. https://doi.org/10.1093/isq/sqab005

Erlich, A., \& Garner, C. (2021b). Is pro-Kremlin Disinformation Effective? Evidence from Ukraine. The International Journal of Press/Politics, 194016122110452. https://doi.org/10.1177/19401612211045221

EU Vs. Disinfo. (2021). Disinformation Build Up: Pro-Kremlin Media Reinvigorate Their Focus on Ukraine. EU Vs. Disinfo Disinformation Review, 238. https://euvsdisinfo.eu/disinformation-build-up-pro-kremlin-media-reinvigorate-theirfocus-on-ukraine/

Frederick, S. (2005). Cognitive Reflection and Decision Making. The Journal of Economic Perspectives, 19(4), 25-42. http://www.jstor.org/stable/4134953

Freelon, D., \& Lokot, T. (2020). Russian Twitter disinformation campaigns reach across the American political spectrum. Harvard Kennedy School Misinformation Review, 1(1). https://doi.org/10.37016/mr-2020-003

Frye, T. (2010). Building States and Markets After Communism: The Perils of Polarized Democracy. Cambridge University Press.

Gawronski, B. (2021). Partisan bias in the identification of fake news. Trends in Cognitive Sciences, 25(9), 723-724. https://doi.org/10.1016/j.tics.2021.05.001

Gerber, T. P., \& Zavisca, J. (2016). Does Russian Propaganda Work? The Washington Quarterly, 39(2), 79-98. https://doi.org/10.1080/0163660X.2016.1204398

Haran, U., Ritov, I., \& Mellers, B. A. (2013). The role of actively open-minded thinking in information acquisition, accuracy, and calibration. Judgment and Decision Making, 8(3), 14.

Helmus, T. C., Bodine-Baron, E., Radin, A., Magnuson, M., Mendelsohn, J., Marcellino, W., Bega, A., \& Winkelman, Z. (2018). Russian Social Media Influence: Understanding Russian Propaganda in Eastern Europe. Rand Corporation.

Jankowicz, N. (2020). How to Lose the Information War: Russia, Fake News, and the Future of Conflict. Bloomsbury Publishing.

Johnson, I. (2005). Political Trust in Societies Under Transformation: A Comparative Analysis of Poland and Ukraine. International Journal of Sociology, 35(2), 63-84. https://doi.org/10.1080/00207659.2005.11043144

Kahan, D. M. (2013). Ideology, motivated reasoning, and cognitive reflection. Judgment and Decision Making, 8(4), 18. 
Kahan, D. M., Peters, E., Dawson, E. C., \& Slovic, P. (2017). Motivated numeracy and enlightened self-government. Behavioural Public Policy, 1(1), 54-86. https://doi.org/10.1017/bpp.2016.2

Kahan, D. M., Peters, E., Wittlin, M., Slovic, P., Ouellette, L. L., Braman, D., \& Mandel, G. (2012). The polarizing impact of science literacy and numeracy on perceived climate change risks. Nature Climate Change, 2(10), 732-735. https://doi.org/10.1038/nclimate1547

Karlsen, G. H. (2016). Tools of Russian Influence: Information and Propaganda. In J. Haaland Matlary \& T. Heier (Eds.), Ukraine and Beyond: Russia's Strategic Security Challenge to Europe (pp. 181-208). Springer International Publishing. https://doi.org/10.1007/978-3319-32530-9 9

Khaldarova, I., \& Pantti, M. (2016). Fake News. Journalism Practice, 10(7), 891-901. https://doi.org/10.1080/17512786.2016.1163237

King, G., Pan, J., \& Roberts, M. E. (2013). How Censorship in China Allows Government Criticism but Silences Collective Expression. American Political Science Review, 107(02), 326-343. https://doi.org/10.1017/S0003055413000014

Koposov, N. (2017). Memory Laws, Memory Wars: The Politics of the Past in Europe and Russia. Cambridge University Press.

Kragh, M., \& Åsberg, S. (2017). Russia’s strategy for influence through public diplomacy and active measures: The Swedish case. Journal of Strategic Studies, 40(6), 773-816. https://doi.org/10.1080/01402390.2016.1273830

Kulyk, V. (2011). Language identity, linguistic diversity and political cleavages: Evidence from Ukraine. Nations and Nationalism, 17(3), 627-648. https://doi.org/10.1111/j.14698129.2011.00493.x

Kulyk, V. (2016). National identity in Ukraine: Impact of Euromaidan and the war. Europe-Asia Studies, 68(4), 588-608.

Kulyk, V. (2018). Shedding Russianness, recasting Ukrainianness: The post-Euromaidan dynamics of ethnonational identifications in Ukraine. Post-Soviet Affairs, 34(2-3), 119 138.

Kulyk, V. (2019). Identity in Transformation: Russian-speakers in Post-Soviet Ukraine. EuropeAsia Studies, 71(1), 156-178. https://doi.org/10.1080/09668136.2017.1379054

Kuru, O., Pasek, J., \& Traugott, M. W. (2017). Motivated Reasoning in the Perceived Credibility of Public Opinion Polls. Public Opinion Quarterly, 81(2), 422-446. https://doi.org/10.1093/poq/nfx018

Mahairas, A., \& Dvilyanski, M. (2018). Disinformation - Дезинформация (Dezinformatsiya). The Cyber Defense Review, 3(3), 21-28. https://www.jstor.org/stable/26554993

Martel, C., Pennycook, G., \& Rand, D. G. (2020). Reliance on emotion promotes belief in fake news. Cognitive Research: Principles and Implications, 5(1), 47. https://doi.org/10.1186/s41235-020-00252-3

McKee, R., Murphy, A., Richardson, E., Roberts, B., Haerpfer, C., \& McKee, M. (2013). Do citizens of the former Soviet Union trust state institutions, and why? East European Politics, 29(4), 377-396. https://doi.org/10.1080/21599165.2013.821981

McNair, B. (2006). Glasnost, Perestroika and the Soviet Media. Routledge. 
Meiselman, W., Pilon, J. G., Lenczowski, J., Dziak, J. J., Godson, R., Shultz, R. H., Levchenko, S., Bennett, R. K., Jacobson, K., Maitre, J., \& Goldsmith, J. (1987). Soviet

Disinformation and the News. Political Communication, 4(1), 29-64. https://doi.org/10.1080/10584609.1987.9962807

Mejias, U. A., \& Vokuev, N. E. (2017). Disinformation and the media: The case of Russia and Ukraine. Media, Culture \& Society, 39(7), 1027-1042. https://doi.org/10.1177/0163443716686672

Munger, K. (2020). All the News That's Fit to Click: The Economics of Clickbait Media. Political Communication, 37(3), 376-397. https://doi.org/10.1080/10584609.2019.1687626

Noutcheva, G. (2018). Whose legitimacy? The EU and Russia in contest for the eastern neighbourhood. Democratization, 25(2), 312-330. https://doi.org/10.1080/13510347.2017.1363186

Onuch, O., \& Hale, H. E. (2018). Capturing ethnicity: The case of Ukraine. Post-Soviet Affairs, 34(2-3), 84-106. https://doi.org/10.1080/1060586X.2018.1452247

Peisakhin, L., \& Rozenas, A. (2018). Electoral Effects of Biased Media: Russian Television in Ukraine: Electoral Effects of Biased Media. American Journal of Political Science, 62(3), 535-550. https://doi.org/10.1111/ajps.12355

Pennycook, G., Cannon, T. D., \& Rand, D. G. (2018). Prior exposure increases perceived accuracy of fake news. Journal of Experimental Psychology: General, 147(12), 18651880. https://doi.org/10.1037/xge0000465

Pennycook, G., Cheyne, J. A., Koehler, D. J., \& Fugelsang, J. A. (2020). On the belief that beliefs should change according to evidence: Implications for conspiratorial, moral, paranormal, political, religious, and science beliefs. Judgment and Decision Making, 14(4), 476-498. https://doi.org/10.31234/osf.io/a7k96

Pennycook, G., \& Rand, D. G. (2019). Lazy, not biased: Susceptibility to partisan fake news is better explained by lack of reasoning than by motivated reasoning. Cognition, 188, 3950. https://doi.org/10.1016/j.cognition.2018.06.011

Pennycook, G., \& Rand, D. G. (2021). The Psychology of Fake News. Trends in Cognitive Sciences, 25(5), 388-402. https://doi.org/10.1016/j.tics.2021.02.007

Pomerantsev, P., \& Weiss, M. (2014). The Menace of Unreality: How the Kremlin Weaponizes Information, Culture and Money (p. 44). Institute of Modern Russia.

Ryabinska, N. (2011). The Media Market and Media Ownership in Post-Communist Ukraine. Problems of Post-Communism, 58(6), 3-20. https://doi.org/10.2753/PPC10758216580601

Shekhovtsov, A. (2011). The Creeping Resurgence of the Ukrainian Radical Right? The Case of the Freedom Party. Europe-Asia Studies, 63(2), 203-228. https://doi.org/10.1080/09668136.2011.547696

Shekhovtsov, A., \& Umland, A. (2014). The Maidan and Beyond: Ukraine's Radical Right. Journal of Democracy, 25(3), 58-63. https://doi.org/10.1353/jod.2014.0051

Shenhav, A., Rand, D. G., \& Greene, J. D. (2012). Divine intuition: Cognitive style influences belief in God. Journal of Experimental Psychology: General, 141(3), 423-428. https://doi.org/10.1037/a0025391 
Shevel, O. (2002). Nationality in Ukraine: Some Rules of Engagement: East European Politics and Societies, 16(2), 386-413. https://doi.org/10.1177/088832540201600203

Shultz, R. H., \& Godson, R. (1984). Dezinformatsia: Active Measures in Soviet Strategy. Pergamon-Brassey's.

Stanovich, K. E., \& West, R. F. (1997). Reasoning independently of prior belief and individual differences in actively open-minded thinking. Journal of Educational Psychology, 89(2), 342. https://doi.org/10.1037/0022-0663.89.2.342

Tappin, B. M., Pennycook, G., \& Rand, D. G. (2020). Thinking clearly about causal inferences of politically motivated reasoning: Why paradigmatic study designs often undermine causal inference. Current Opinion in Behavioral Sciences, 34, 81-87. https://doi.org/10.1016/j.cobeha.2020.01.003

Tappin, B. M., Pennycook, G., \& Rand, D. G. (2021). Rethinking the link between cognitive sophistication and politically motivated reasoning. Journal of Experimental Psychology General, 150(6), 1095-1114. https://doi.org/10.1037/xge0000974

Thomson, K. S., \& Oppenheimer, D. M. (2016). Investigating an alternate form of the cognitive reflection test. Judgment and Decision Making, 11(1), 15.

Xia, Y., Lukito, J., Zhang, Y., Wells, C., Kim, S. J., \& Tong, C. (2019). Disinformation, performed: Self-presentation of a Russian IRA account on Twitter. Information, Communication \& Society, 22(11), 1646-1664. https://doi.org/10.1080/1369118X.2019.1621921 


\title{
Online Appendix for: Does Analytic Thinking Insulate Against Pro-Kremlin Disinformation
}

Aaron Erlich ${ }^{1,2}$, Calvin Garner ${ }^{3}$, Gordon Pennycook ${ }^{4,5}$, and David Rand ${ }^{6,7}$

\author{
${ }^{1}$ Department of Political Science \\ McGill University, 855 Rue Sherbrooke Ouest \\ Montréal, QC H2T 2A1 Canada \\ aaron.erlich@mcgill.ca \\ ${ }^{2}$ Centre for the Study of Democratic Citizenship \\ ${ }^{3}$ Department of Political Science, University of Washington \\ ${ }^{4}$ Department of Psychology, University of Regina \\ ${ }^{5}$ Hill/Levene Schools of Business, University of Regina \\ ${ }^{6}$ Sloan School, MIT \\ ${ }^{7}$ Department of Brain and Cognitive Sciences, MIT
}

V 1.02 


\section{Contents}

1 Study 123

1.1 Summary Statistics . . . . . . . . . . . . . . . . . . . 3

1.2 Summary Statistics Unscaled . . . . . . . . . . . . . . . . . . . 3

1.3 Regression Models . . . . . . . . . . . . . . . . . . . . . . . . . 4

2 Study $2 \quad 7$

2.1 Summary Statistics . . . . . . . . . . . . . . . . . . . . 7

2.2 Summary Statistics Unscaled . . . . . . . . . . . . . . . . . . . 7

2.3 Regression Models . . . . . . . . . . . . . . . . . . . . . 8

3 Robustness Checks 11

3.1 Zero-Order Correlations . . . . . . . . . . . . . . . . . . . . . . . 11

3.2 Study 1: Alternative CRT \& AOT Measures . . . . . . . . . . . . . . . . 15

4 List of Materials $\quad 16$

5 Sample Stories $\quad 18$

6 Pre-registrations $\quad 19$ 


\section{Study 1}

\subsection{Summary Statistics}

\begin{tabular}{lrrrrrr}
\hline Variable & Min. & Mean & Median & Max. & Std. Error & Std. Dev. \\
\hline Belief & 1.00 & 2.88 & 3.00 & 6.00 & 0.01 & 1.62 \\
StoryTrue & 0.00 & 0.25 & 0.00 & 1.00 & 0.00 & 0.43 \\
CRT & -1.59 & -0.00 & 0.09 & 2.34 & 0.02 & 1.00 \\
AOT & -4.88 & 0.00 & 0.08 & 5.69 & 0.02 & 1.00 \\
RussianOrientation & -1.24 & -0.00 & -0.03 & 1.80 & 0.02 & 1.00 \\
ProRussiaPoliOrientation & -1.13 & -0.00 & 0.60 & 2.32 & 0.02 & 1.00 \\
Education & 1.00 & 5.45 & 6.00 & 6.00 & 0.02 & 1.04 \\
Income & 5.00 & 6.61 & 6.00 & 20.00 & 0.03 & 1.46 \\
Age & 18.00 & 37.99 & 37.00 & 65.00 & 0.22 & 9.72 \\
Female & 1.00 & 1.55 & 2.00 & 2.00 & 0.01 & 0.50 \\
\hline
\end{tabular}

\subsection{Summary Statistics Unscaled}

\begin{tabular}{lrrrrrr}
\hline Variable & Min. & Mean & Median & Max. & Std. Error & Std. Dev. \\
\hline Belief & 1.00 & 2.88 & 3.00 & 6.00 & 0.01 & 1.62 \\
StoryTrue & 0.00 & 0.25 & 0.00 & 1.00 & 0.00 & 0.43 \\
CRTUnscaled & 0.00 & 0.40 & 0.43 & 1.00 & 0.01 & 0.25 \\
AOTUnscaled & 0.00 & 0.46 & 0.47 & 1.00 & 0.00 & 0.09 \\
RussianOrientationUnscaled & -5.00 & -0.91 & -1.00 & 5.00 & 0.07 & 3.29 \\
ProRussiaPoliOrientationUnscaled & -1.00 & -0.35 & 0.00 & 1.00 & 0.01 & 0.58 \\
Education & 1.00 & 5.45 & 6.00 & 6.00 & 0.02 & 1.04 \\
Income & 5.00 & 6.61 & 6.00 & 20.00 & 0.03 & 1.46 \\
Age & 18.00 & 37.99 & 37.00 & 65.00 & 0.22 & 9.72 \\
Female & 1.00 & 1.55 & 2.00 & 2.00 & 0.01 & 0.50 \\
\hline
\end{tabular}


Table 1: Study 1 Linear Models

\begin{tabular}{|c|c|c|c|c|c|c|c|c|c|c|c|}
\hline & \multicolumn{11}{|c|}{ Dependent variable: } \\
\hline & (1) & (2) & (3) & (4) & (5) & $\begin{array}{l}\text { Belief } \\
(6)\end{array}$ & (7) & (8) & (9) & (10) & (11) \\
\hline Constant & $\begin{array}{c}2.487^{* * * *} \\
(0.067)\end{array}$ & $\begin{array}{c}2.487^{* * * *} \\
(0.067)\end{array}$ & $\begin{array}{c}2.487^{* * *} \\
(0.067)\end{array}$ & $\begin{array}{c}2.489^{* * *} \\
(0.066)\end{array}$ & $\begin{array}{c}2.488^{* * *} \\
(0.066)\end{array}$ & $\begin{array}{c}2.484^{* * * *} \\
(0.067)\end{array}$ & $\begin{array}{c}2.489^{* * *} \\
(0.067)\end{array}$ & $\begin{array}{c}2.653^{* * * *} \\
(0.451)\end{array}$ & $\begin{array}{c}2.694^{* * *} \\
(0.438)\end{array}$ & $\begin{array}{c}2.223^{* * *} \\
(0.489)\end{array}$ & $\begin{array}{c}2.200^{* * * *} \\
(0.496)\end{array}$ \\
\hline StoryTrue & $\begin{array}{c}1.577^{* * * *} \\
(0.160)\end{array}$ & $\begin{array}{c}1.577^{* * *} \\
(0.160)\end{array}$ & $\begin{array}{c}1.577^{* * *} \\
(0.160)\end{array}$ & $\begin{array}{c}1.575^{* * *} \\
(0.159)\end{array}$ & $\begin{array}{c}1.576^{* * * *} \\
(0.160)\end{array}$ & $\begin{array}{c}1.582^{* * *} \\
(0.159)\end{array}$ & $\begin{array}{c}1.575^{* * *} \\
(0.160)\end{array}$ & $\begin{array}{c}1.558^{* * * *} \\
(0.161)\end{array}$ & $\begin{array}{c}1.562^{* * *} \\
(0.161)\end{array}$ & $\begin{array}{c}1.580^{* * *} \\
(0.161)\end{array}$ & $\begin{array}{c}1.574^{* * *} \\
(0.162)\end{array}$ \\
\hline CRT & $\begin{array}{l}-0.030 \\
(0.019)\end{array}$ & & & $\begin{array}{c}-0.075^{* * *} \\
(0.017)\end{array}$ & & $\begin{array}{c}-0.052^{* * *} \\
(0.018)\end{array}$ & & $\begin{array}{c}-0.053^{* *} \\
(0.025)\end{array}$ & & $\begin{array}{l}-0.019 \\
(0.026)\end{array}$ & \\
\hline АOT & & $\begin{array}{c}-0.044^{* *} \\
(0.019)\end{array}$ & & & $\begin{array}{c}-0.053^{* * *} \\
(0.018)\end{array}$ & & $\begin{array}{c}-0.061^{* * *} \\
(0.019)\end{array}$ & & $\begin{array}{l}-0.018 \\
(0.023)\end{array}$ & & $\begin{array}{l}-0.029 \\
(0.024)\end{array}$ \\
\hline cogStyleAgg & & & $\begin{array}{c}-0.053^{* * *} \\
(0.017)\end{array}$ & & & & & & & & \\
\hline RussianOrientation & & & & $\begin{array}{c}0.361^{* * *} \\
(0.024)\end{array}$ & $\begin{array}{c}0.352^{* * *} \\
(0.024)\end{array}$ & & & $\begin{array}{c}0.363^{* * *} \\
(0.031)\end{array}$ & $\begin{array}{c}0.356^{* * *} \\
(0.030)\end{array}$ & & \\
\hline ProRussiaPoliOrientation & & & & & & $\begin{array}{c}0.216^{* * *} \\
(0.020)\end{array}$ & $\begin{array}{c}0.212^{* * *} \\
(0.020)\end{array}$ & & & $\begin{array}{c}0.196^{* * *} \\
(0.026)\end{array}$ & $\begin{array}{c}0.191^{* * * *} \\
(0.027)\end{array}$ \\
\hline CRT:StoryTrue & $\begin{array}{c}0.116^{* * *} \\
(0.032)\end{array}$ & & & $\begin{array}{c}0.174^{* * *} \\
(0.032)\end{array}$ & & $\begin{array}{c}0.147^{* * * *} \\
(0.032)\end{array}$ & & $\begin{array}{c}0.145^{* * *} \\
(0.041)\end{array}$ & & $\begin{array}{c}0.113^{* * *} \\
(0.042)\end{array}$ & \\
\hline AOT:StoryTrue & & $\begin{array}{c}0.112^{* * *} \\
(0.030)\end{array}$ & & & $\begin{array}{c}0.123^{* * *} \\
(0.029)\end{array}$ & & $\begin{array}{c}0.136^{* * *} \\
(0.030)\end{array}$ & & $\begin{array}{c}0.096^{* *} \\
(0.041)\end{array}$ & & $\begin{array}{c}0.115^{* * *} \\
(0.044)\end{array}$ \\
\hline cogStyleAgg:StoryTrue & & & $\begin{array}{c}0.167^{* * *} \\
(0.028)\end{array}$ & & & & & & & & \\
\hline CRT:RussianOrientation & & & & $\begin{array}{l}-0.012 \\
(0.018)\end{array}$ & & & & $\begin{array}{l}-0.013 \\
(0.026)\end{array}$ & & & \\
\hline AOT:RussianOrientation & & & & & $\begin{array}{c}-0.032^{*} \\
(0.018)\end{array}$ & & & & $\begin{array}{l}-0.036 \\
(0.026)\end{array}$ & & \\
\hline StoryTrue:RussianOrientation & & & & $\begin{array}{c}-0.470^{* * *} \\
(0.040)\end{array}$ & $\begin{array}{c}-0.451^{* * *} \\
(0.039)\end{array}$ & & & $\begin{array}{c}-0.448^{* * *} \\
(0.047)\end{array}$ & $\begin{array}{c}-0.431^{* * *} \\
(0.046)\end{array}$ & & \\
\hline CRT:StoryTrue:RussianOrientation & & & & $\begin{array}{c}0.014 \\
(0.027)\end{array}$ & & & & $\begin{array}{l}0.046 \\
(0.040)\end{array}$ & & & \\
\hline АOT:StoryTrue:RussianOrientation & & & & & $\begin{array}{c}0.044 \\
(0.029)\end{array}$ & & & & $\begin{array}{l}0.041 \\
(0.044)\end{array}$ & & \\
\hline CRT:ProRussiaPoliOrientation & & & & & & $\begin{array}{l}0.036^{* * *} \\
(0.017)\end{array}$ & & & & $\begin{array}{c}0.035 \\
(0.025)\end{array}$ & \\
\hline AOT:ProRussiaPoliOrientation & & & & & & & $\begin{array}{l}-0.023 \\
(0.018)\end{array}$ & & & & $\begin{array}{l}-0.030 \\
(0.022)\end{array}$ \\
\hline StoryTrue:ProRussiaPoliOrientation & & & & & & $\begin{array}{c}-0.305^{* * *} \\
(0.035)\end{array}$ & $\begin{array}{c}-0.296^{* * * *} \\
(0.035)\end{array}$ & & & $\begin{array}{c}-0.276^{* * *} \\
(0.048)\end{array}$ & $\begin{array}{c}-0.272^{* * *} \\
(0.048)\end{array}$ \\
\hline CRT:StoryTrue:ProRussiaPoliOrientation & & & & & & $\begin{array}{c}-0.054^{* *} \\
(0.027)\end{array}$ & & & & $\begin{array}{l}-0.040 \\
(0.037)\end{array}$ & \\
\hline AOT:StoryTrue:ProRussiaPoliOrientation & & & & & & & $\begin{array}{l}0.025 \\
(0.029)\end{array}$ & & & & $\begin{array}{c}0.029 \\
(0.039)\end{array}$ \\
\hline Demographic Controls & No & No & No & No & No & No & No & Yes & Yes & Yes & Yes \\
\hline Observations & 32,640 & 32,640 & 32,640 & 32,640 & 32,640 & 32,640 & 32,640 & 16,480 & 16,480 & 16,480 & 16,480 \\
\hline & 0.179 & 0.179 & 0.181 & 0.217 & 0.216 & 0.193 & 0.193 & 0.217 & 0.216 & 0.192 & 0.192 \\
\hline $\begin{array}{l}\text { Adjusted } R^{2} \\
\text { F Statistic }(\mathrm{df}=32639)\end{array}$ & $\begin{array}{c}0.179 \\
34.384^{* * *}\end{array}$ & $\begin{array}{c}0.179 \\
35.796^{* * *}\end{array}$ & $\begin{array}{c}0.181 \\
38.956^{* * *}\end{array}$ & $\begin{array}{c}0.217 \\
49.18^{* * *}\end{array}$ & $\begin{array}{c}0.216 \\
49.595^{* * *}\end{array}$ & $\begin{array}{c}0.193 \\
34.589^{* * *}\end{array}$ & $\begin{array}{c}0.193 \\
32.726^{* * *}\end{array}$ & $\begin{array}{c}0.216 \\
19.265^{* * *}\end{array}$ & $\begin{array}{c}0.215 \\
20.71^{* * *}\end{array}$ & $\begin{array}{c}0.191 \\
11.609^{* * *}\end{array}$ & $\begin{array}{c}0.191 \\
12.465^{* * *}\end{array}$ \\
\hline
\end{tabular}


Table 2: Study 1 Multilevel Models

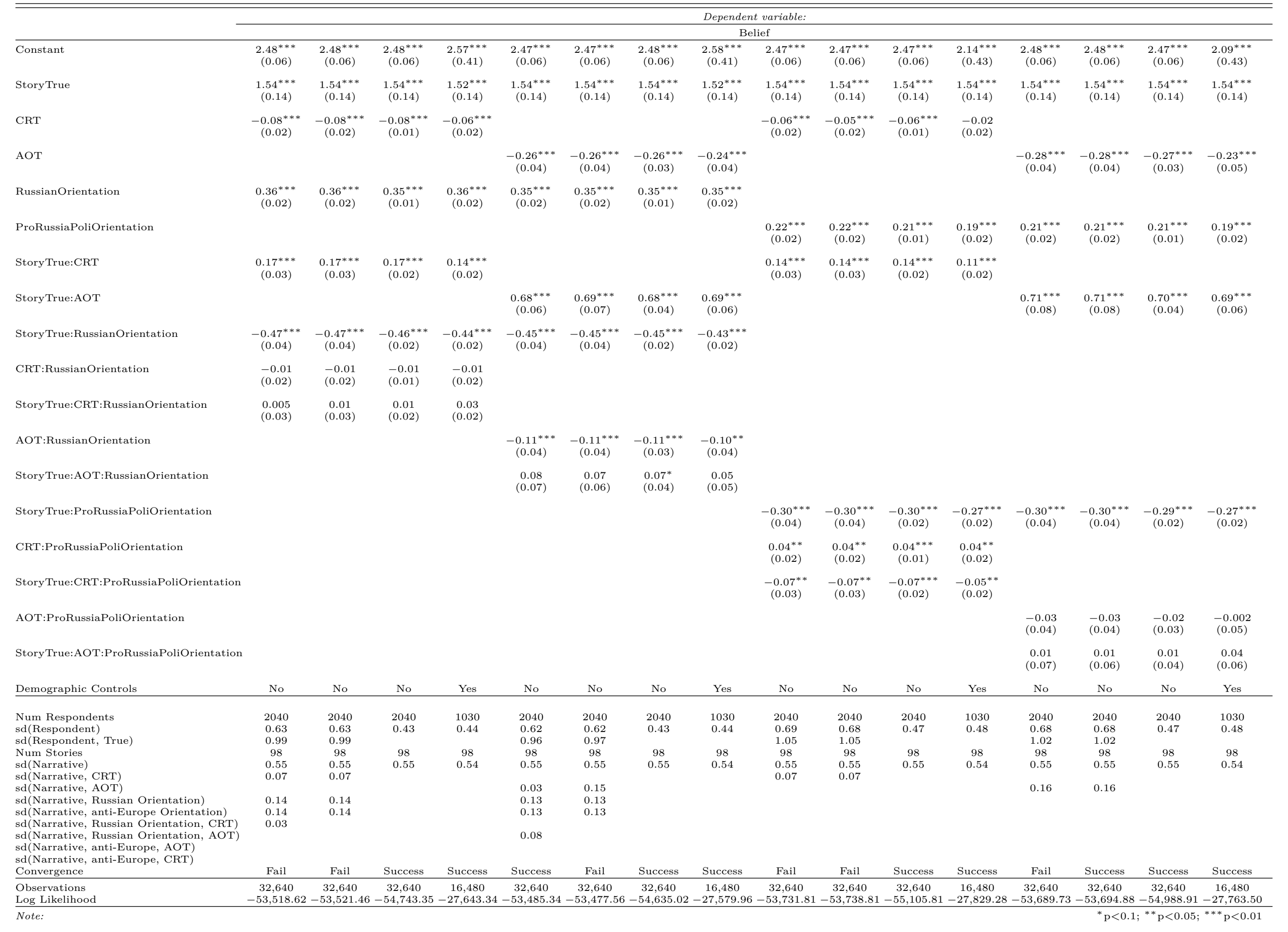


Table 3: Study 1 Linear Models with Theme and Strategy Controls

\begin{tabular}{|c|c|c|c|c|}
\hline & \multicolumn{4}{|c|}{ Dependent variable: } \\
\hline & (1) & (2) & $\begin{array}{l}\text { Belief } \\
\text { (3) }\end{array}$ & (4) \\
\hline Constant & $\begin{array}{c}2.728^{* * *} \\
(0.469)\end{array}$ & $\begin{array}{c}2.769^{* * *} \\
(0.456)\end{array}$ & $\begin{array}{c}2.298^{* * *} \\
(0.501)\end{array}$ & $\begin{array}{c}2.275^{* * *} \\
(0.507)\end{array}$ \\
\hline ProRussiaPoliOrientation & & & $\begin{array}{c}0.196^{* * *} \\
(0.026)\end{array}$ & $\begin{array}{c}0.191^{* * *} \\
(0.027)\end{array}$ \\
\hline CRT & $\begin{array}{c}-0.053^{* *} \\
(0.025)\end{array}$ & & $\begin{array}{l}-0.019 \\
(0.026)\end{array}$ & \\
\hline $\mathrm{AOT}$ & & $\begin{array}{l}-0.018 \\
(0.023)\end{array}$ & & $\begin{array}{l}-0.029 \\
(0.024)\end{array}$ \\
\hline StoryTrue & $\begin{array}{c}1.501^{* * *} \\
(0.164)\end{array}$ & $\begin{array}{c}1.505^{* * *} \\
(0.165)\end{array}$ & $\begin{array}{c}1.523^{* * *} \\
(0.164)\end{array}$ & $\begin{array}{c}1.517^{* * *} \\
(0.165)\end{array}$ \\
\hline RussianOrientation & $\begin{array}{c}0.363^{* * *} * \\
(0.031)\end{array}$ & $\begin{array}{c}0.356^{* * *} \\
(0.030)\end{array}$ & & \\
\hline Age & $\begin{array}{l}-0.001 \\
(0.002)\end{array}$ & $\begin{array}{l}-0.001 \\
(0.002)\end{array}$ & $\begin{array}{c}0.003 \\
(0.002)\end{array}$ & $\begin{array}{c}0.003 \\
(0.002)\end{array}$ \\
\hline Female & $\begin{array}{c}0.015 \\
(0.041)\end{array}$ & $\begin{array}{c}0.017 \\
(0.042)\end{array}$ & $\begin{array}{l}0.077^{*} \\
(0.044)\end{array}$ & $\begin{array}{l}0.076^{*} \\
(0.045)\end{array}$ \\
\hline factor(Education) 2 & $\begin{array}{l}-0.221 \\
(0.438)\end{array}$ & $\begin{array}{l}-0.268 \\
(0.424)\end{array}$ & $\begin{array}{c}0.041 \\
(0.479)\end{array}$ & $\begin{array}{c}0.075 \\
(0.485)\end{array}$ \\
\hline factor(Education) 3 & $\begin{array}{l}-0.265 \\
(0.438)\end{array}$ & $\begin{array}{l}-0.306 \\
(0.425)\end{array}$ & $\begin{array}{c}0.051 \\
(0.478)\end{array}$ & $\begin{array}{c}0.096 \\
(0.485)\end{array}$ \\
\hline factor(Education) 4 & $\begin{array}{l}-0.253 \\
(0.434)\end{array}$ & $\begin{array}{l}-0.293 \\
(0.420)\end{array}$ & $\begin{array}{c}0.089 \\
(0.476)\end{array}$ & $\begin{array}{c}0.121 \\
(0.483)\end{array}$ \\
\hline factor(Education) 5 & $\begin{array}{l}-0.323 \\
(0.433)\end{array}$ & $\begin{array}{l}-0.367 \\
(0.420)\end{array}$ & $\begin{array}{c}0.002 \\
(0.474)\end{array}$ & $\begin{array}{c}0.042 \\
(0.480)\end{array}$ \\
\hline factor(Education) 6 & $\begin{array}{l}-0.262 \\
(0.431)\end{array}$ & $\begin{array}{l}-0.307 \\
(0.417)\end{array}$ & $\begin{array}{c}0.003 \\
(0.471)\end{array}$ & $\begin{array}{c}0.043 \\
(0.477)\end{array}$ \\
\hline Income & $\begin{array}{c}0.018 \\
(0.011)\end{array}$ & $\begin{array}{c}0.017 \\
(0.011)\end{array}$ & $\begin{array}{c}-0.0003 \\
(0.012)\end{array}$ & $\begin{array}{l}-0.001 \\
(0.012)\end{array}$ \\
\hline as_factor(theme)historical & $\begin{array}{l}-0.042 \\
(0.164)\end{array}$ & $\begin{array}{l}-0.042 \\
(0.164)\end{array}$ & $\begin{array}{l}-0.042 \\
(0.164)\end{array}$ & $\begin{array}{l}-0.042 \\
(0.164)\end{array}$ \\
\hline as_factor(theme)military & $\begin{array}{l}-0.041 \\
(0.179)\end{array}$ & $\begin{array}{l}-0.041 \\
(0.179)\end{array}$ & $\begin{array}{l}-0.041 \\
(0.180)\end{array}$ & $\begin{array}{l}-0.041 \\
(0.180)\end{array}$ \\
\hline as_factor(theme)political & $\begin{array}{c}0.009 \\
(0.182)\end{array}$ & $\begin{array}{c}0.009 \\
(0.182)\end{array}$ & $\begin{array}{c}0.009 \\
(0.182)\end{array}$ & $\begin{array}{c}0.009 \\
(0.182)\end{array}$ \\
\hline StrategyUndermineUkraine & $\begin{array}{l}-0.002 \\
(0.171)\end{array}$ & $\begin{array}{l}-0.002 \\
(0.171)\end{array}$ & $\begin{array}{l}-0.002 \\
(0.172)\end{array}$ & $\begin{array}{l}-0.002 \\
(0.172)\end{array}$ \\
\hline StrategyProRussia & $\begin{array}{c}-0.168^{*} \\
(0.100)\end{array}$ & $\begin{array}{c}-0.168^{*} \\
(0.099)\end{array}$ & $\begin{array}{c}-0.168^{*} \\
(0.098)\end{array}$ & $\begin{array}{c}-0.168^{*} \\
(0.098)\end{array}$ \\
\hline CRT:StoryTrue & $\begin{array}{c}0.145^{* * *} \\
(0.041)\end{array}$ & & $\begin{array}{c}0.113^{* * *} \\
(0.042)\end{array}$ & \\
\hline CRT:RussianOrientation & $\begin{array}{l}-0.013 \\
(0.026)\end{array}$ & & & \\
\hline AOT:StoryTrue & & $\begin{array}{c}0.096^{* *} \\
(0.041)\end{array}$ & & $\begin{array}{c}0.115^{* * *} \\
(0.043)\end{array}$ \\
\hline AOT:RussianOrientation & & $\begin{array}{l}-0.036 \\
(0.026)\end{array}$ & & \\
\hline StoryTrue:RussianOrientation & $\begin{array}{c}-0.448^{* * *} \\
(0.047)\end{array}$ & $\begin{array}{c}-0.431^{* * *} \\
(0.046)\end{array}$ & & \\
\hline CRT:StoryTrue:RussianOrientation & $\begin{array}{c}0.046 \\
(0.040)\end{array}$ & & & \\
\hline AOT:StoryTrue:RussianOrientation & & $\begin{array}{c}0.041 \\
(0.044)\end{array}$ & & \\
\hline CRT:ProRussiaPoliOrientation & & & $\begin{array}{c}0.035 \\
(0.025)\end{array}$ & \\
\hline AOT:ProRussiaPoliOrientation & & & & $\begin{array}{l}-0.030 \\
(0.022)\end{array}$ \\
\hline StoryTrue:ProRussiaPoliOrientation & & & $\begin{array}{c}-0.276^{* * *} \\
(0.048)\end{array}$ & $\begin{array}{c}-0.272^{* * *} \\
(0.047)\end{array}$ \\
\hline CRT:StoryTrue:ProRussiaPoliOrientation & & & $\begin{array}{l}-0.040 \\
(0.037)\end{array}$ & \\
\hline AOT:StoryTrue:ProRussiaPoliOrientation & & & & $\begin{array}{c}0.029 \\
(0.039)\end{array}$ \\
\hline Observations & 16,480 & 16,480 & 16,480 & 16,480 \\
\hline$R^{2}$ & 0.219 & 0.218 & 0.194 & 0.194 \\
\hline Adjusted $\mathrm{R}^{2}$ & 0.218 & 0.217 & 0.193 & 0.193 \\
\hline F Statistic $(\mathrm{df}=16479)$ & $16.474^{* * *}$ & $17.3^{* * *}$ & $10.438^{* * *}$ & $10.594 * * *$ \\
\hline
\end{tabular}




\section{Study 2}

\subsection{Summary Statistics}

\begin{tabular}{lrrrrrr}
\hline Variable & Min. & Mean & Median & Max. & Std. Error & Std. Dev. \\
\hline Belief & -3.00 & -0.51 & 0.00 & 3.00 & 0.00 & 1.88 \\
StoryTrue & 0.00 & 0.25 & 0.00 & 1.00 & 0.00 & 0.43 \\
CRT & -1.31 & 0.00 & 0.25 & 1.81 & 0.01 & 1.00 \\
AOT & -2.04 & 0.00 & 0.03 & 2.92 & 0.01 & 1.00 \\
RussianOrientation & -1.20 & 0.00 & -0.04 & 1.90 & 0.01 & 1.00 \\
RussiaNotAThreat & -2.02 & 0.00 & -0.27 & 1.47 & 0.01 & 1.00 \\
Education & 1.00 & 3.76 & 3.00 & 6.00 & 0.02 & 1.51 \\
Income & 1.00 & 3.12 & 3.00 & 4.00 & 0.01 & 0.75 \\
Age & 18.00 & 51.97 & 53.00 & 95.00 & 0.18 & 17.73 \\
Female & 1.00 & 1.63 & 2.00 & 2.00 & 0.00 & 0.48 \\
\hline
\end{tabular}

\subsection{Summary Statistics Unscaled}

\begin{tabular}{lrrrrrrr}
\hline Variable & Min. & Mean & Median & Max. & Std. Error & Std. Dev. \\
\hline Belief & -3.00 & -0.51 & 0.00 & 3.00 & 0.00 & 1.88 \\
StoryTrue & 0.00 & 0.25 & 0.00 & 1.00 & 0.00 & 0.43 \\
CRTUnscaled & 0.00 & 0.42 & 0.50 & 1.00 & 0.00 & 0.32 \\
AOTUnscaled & -0.05 & 0.36 & 0.37 & 0.94 & 0.00 & 0.20 \\
RussianOrientationUnscaled & -5.00 & -0.77 & -1.00 & 5.00 & 0.02 & 1.92 \\
RussiaNotAThreatUnscaled & -2.00 & 0.31 & 0.00 & 2.00 & 0.01 & 1.14 \\
Education & 1.00 & 3.76 & 3.00 & 6.00 & 0.02 & 1.51 \\
Income & 1.00 & 3.12 & 3.00 & 4.00 & 0.01 & 0.75 \\
Age & 18.00 & 51.97 & 53.00 & 95.00 & 0.18 & 17.73 \\
Female & 1.00 & 1.63 & 2.00 & 2.00 & 0.00 & 0.48 \\
\hline
\end{tabular}


Table 4: Study 2 Linear Models

\begin{tabular}{|c|c|c|c|c|c|c|c|c|c|c|}
\hline & \multicolumn{10}{|c|}{ Dependent variable: } \\
\hline & (1) & (2) & (3) & (4) & $\mathrm{Be}$ & ief & (7) & (8) & (0) & (10) \\
\hline Constant & $\begin{array}{l}-0.772^{* * *} \\
(0.102)\end{array}$ & $\begin{array}{c}-0.791^{* * *} \\
(0.095)\end{array}$ & $\begin{array}{c}-0.778^{* * *} \\
(0.102)\end{array}$ & $\begin{array}{c}-0.801^{* * *} \\
(0.095)\end{array}$ & $\begin{array}{c}-0.825^{* * *} \\
(0.096)\end{array}$ & $-0.851^{* * *}$ & $\begin{array}{c}-0.661^{* * *} \\
(0.137)\end{array}$ & $-0.659^{* * *}$ & $-0.590^{* * *}$ & $-0.574^{* * *}$ \\
\hline StoryTrue & $\begin{array}{c}1.031^{* * *} \\
(0.220)\end{array}$ & $\begin{array}{c}1.016^{* * *} \\
(0.211)\end{array}$ & $\begin{array}{c}1.033^{* * *} \\
(0.221)\end{array}$ & $\begin{array}{c}1.029^{* * *} \\
(0.211)\end{array}$ & $\begin{array}{c}1.050^{* * * *} \\
(0.209)\end{array}$ & $\begin{array}{c}1.066^{* * *} \\
(0.199)\end{array}$ & $\begin{array}{c}1.031^{* * *} \\
(0.223)\end{array}$ & $\begin{array}{c}1.030^{* * *} \\
(0.213)\end{array}$ & $\begin{array}{c}1.051^{* * *} \\
(0.212)\end{array}$ & $\begin{array}{c}1.068^{* * *} \\
(0.201)\end{array}$ \\
\hline CRT & $\begin{array}{c}-0.113^{* * *} \\
(0.015)\end{array}$ & & $\begin{array}{c}-0.089^{* * *} \\
(0.014)\end{array}$ & & $\begin{array}{c}-0.056^{* * *} \\
(0.014)\end{array}$ & & $\begin{array}{c}-0.068^{* * *} \\
(0.014)\end{array}$ & & $\begin{array}{c}-0.058^{* * *} \\
(0.014)\end{array}$ & \\
\hline АOT & & $\begin{array}{c}-0.041^{* *} \\
(0.020)\end{array}$ & & $\begin{array}{l}-0.026 \\
(0.018)\end{array}$ & & $\begin{array}{c}0.016 \\
(0.017)\end{array}$ & & $\begin{array}{c}-0.040^{* *} \\
(0.019)\end{array}$ & & $\begin{array}{l}-0.027 \\
(0.018)\end{array}$ \\
\hline RussianOrientation & & & $\begin{array}{c}0.315^{* * *} \\
(0.026)\end{array}$ & $\begin{array}{c}0.351 * * * \\
(0.028)\end{array}$ & & & $\begin{array}{c}0.264^{* * * *} \\
(0.024)\end{array}$ & $\begin{array}{c}0.304^{* * *} \\
(0.028)\end{array}$ & & \\
\hline RussiaNotAThreat & & & & & $\begin{array}{c}0.425^{* * *} \\
(0.031)\end{array}$ & $\begin{array}{c}0.428^{* * *} \\
(0.031)\end{array}$ & & & $\begin{array}{c}0.377^{* * * *} \\
(0.029)\end{array}$ & $\begin{array}{c}0.386^{* * * *} \\
(0.030)\end{array}$ \\
\hline CRT:StoryTrue & $\begin{array}{c}0.207^{* * *} \\
(0.025)\end{array}$ & & $\begin{array}{c}0.182^{* * * *} \\
(0.021)\end{array}$ & & $\begin{array}{c}0.157^{* * *} \\
(0.021)\end{array}$ & & $\begin{array}{c}0.182^{* * *} \\
(0.021)\end{array}$ & & $\begin{array}{c}0.156^{* * *} \\
(0.021)\end{array}$ & \\
\hline AOT:StoryTrue & & $\begin{array}{c}0.051 \\
(0.050)\end{array}$ & & $\begin{array}{c}0.028 \\
(0.045)\end{array}$ & & $\begin{array}{l}-0.028 \\
(0.041)\end{array}$ & & $\begin{array}{c}0.031 \\
(0.045)\end{array}$ & & $\begin{array}{l}-0.018 \\
(0.040)\end{array}$ \\
\hline CRT:RussianOrientation & & & $\begin{array}{l}-0.005 \\
(0.012)\end{array}$ & & & & $\begin{array}{l}-0.012 \\
(0.011)\end{array}$ & & & \\
\hline АОТ:RussianOrientation & & & & $\begin{array}{l}-0.027 \\
(0.017)\end{array}$ & & & & $\begin{array}{c}-0.056^{* * *} \\
(0.016)\end{array}$ & & \\
\hline StoryTrue:RussianOrientation & & & $\begin{array}{c}-0.361^{* * *} \\
(0.065)\end{array}$ & $\begin{array}{c}-0.444^{* * *} \\
(0.060)\end{array}$ & & & $\begin{array}{c}-0.359^{* * *} \\
(0.064)\end{array}$ & $\begin{array}{c}-0.442^{* * *} \\
(0.060)\end{array}$ & & \\
\hline CRT:StoryTrue:RussianOrientation & & & $\begin{array}{c}0.023 \\
(0.020)\end{array}$ & & & & $\begin{array}{c}0.024 \\
(0.020)\end{array}$ & & & \\
\hline AOT:StoryTrue:RussianOrientation & & & & $\begin{array}{c}0.094^{* * *} \\
(0.035)\end{array}$ & & & & $\begin{array}{c}0.099^{* * *} \\
(0.035)\end{array}$ & & \\
\hline CRT:RussiaNotAThreat & & & & & $\begin{array}{l}0.022^{*} \\
(0.012)\end{array}$ & & & & $\begin{array}{c}0.011 \\
(0.012)\end{array}$ & \\
\hline АOT:RussiaNotAThreat & & & & & & $\begin{array}{l}-0.017 \\
(0.016)\end{array}$ & & & & $\begin{array}{c}-0.039^{* *} \\
(0.016)\end{array}$ \\
\hline StoryTrue:RussiaNotAThreat & & & & & $\begin{array}{c}-0.556^{* * *} \\
(0.064)\end{array}$ & $\begin{array}{c}-0.601^{* * *} \\
(0.061)\end{array}$ & & & $\begin{array}{c}-0.557^{* * *} \\
(0.065)\end{array}$ & $\begin{array}{c}-0.602^{* * *} \\
(0.060)\end{array}$ \\
\hline CRT:StoryTrue:RussiaNotAThreat & & & & & $\begin{array}{c}-0.067^{* * *} \\
(0.019)\end{array}$ & & & & $\begin{array}{c}-0.068^{* * *} \\
(0.019)\end{array}$ & \\
\hline AOT:StoryTrue:RussiaNotAThreat & & & & & & $\begin{array}{l}0.029 \\
(0.036)\end{array}$ & & & & $\begin{array}{c}0.029 \\
(0.036)\end{array}$ \\
\hline $\begin{array}{l}\text { Demographic Controls } \\
\text { Oblast Strata Fixed Effects }\end{array}$ & $\begin{array}{l}\text { No } \\
\text { No }\end{array}$ & $\begin{array}{l}\text { No } \\
\text { No }\end{array}$ & $\begin{array}{l}\text { No } \\
\text { No }\end{array}$ & $\begin{array}{l}\text { No } \\
\text { No }\end{array}$ & $\begin{array}{l}\text { No } \\
\text { No }\end{array}$ & No & $\begin{array}{l}\text { Yes } \\
\text { Yes }\end{array}$ & $\begin{array}{l}\text { Yes } \\
\text { Yes }\end{array}$ & $\begin{array}{l}\text { Yes } \\
\text { Yes }\end{array}$ & $\begin{array}{l}\text { Yes } \\
\text { Yes }\end{array}$ \\
\hline Observations & 167,237 & 110,320 & 163,727 & 108,609 & 122,638 & 89,511 & 159,689 & 106,280 & 119,623 & 87,516 \\
\hline & 0.060 & 0.053 & 0.081 & 0.080 & 0.100 & 0.095 & 0.096 & 0.096 & 0.117 & 0.114 \\
\hline Adjusted $\mathrm{R}^{2}$ & 0.060 & 0.053 & 0.081 & 0.080 & 0.100 & 0.095 & 0.095 & 0.095 & 0.116 & 0.113 \\
\hline F Statistic $(\mathrm{df}=167236)$ & $42.018^{* * * *}$ & $24.397^{* * *}$ & $44.584^{* * *}$ & $30.591^{* * * *}$ & $43.574^{* * *}$ & $35.468^{* * *}$ & $21.973^{* * *}$ & $16.257^{* * *}$ & $22.798^{* * *}$ & $25.292^{* * *}$ \\
\hline
\end{tabular}


Table 5: Study 2 Multilevel Models

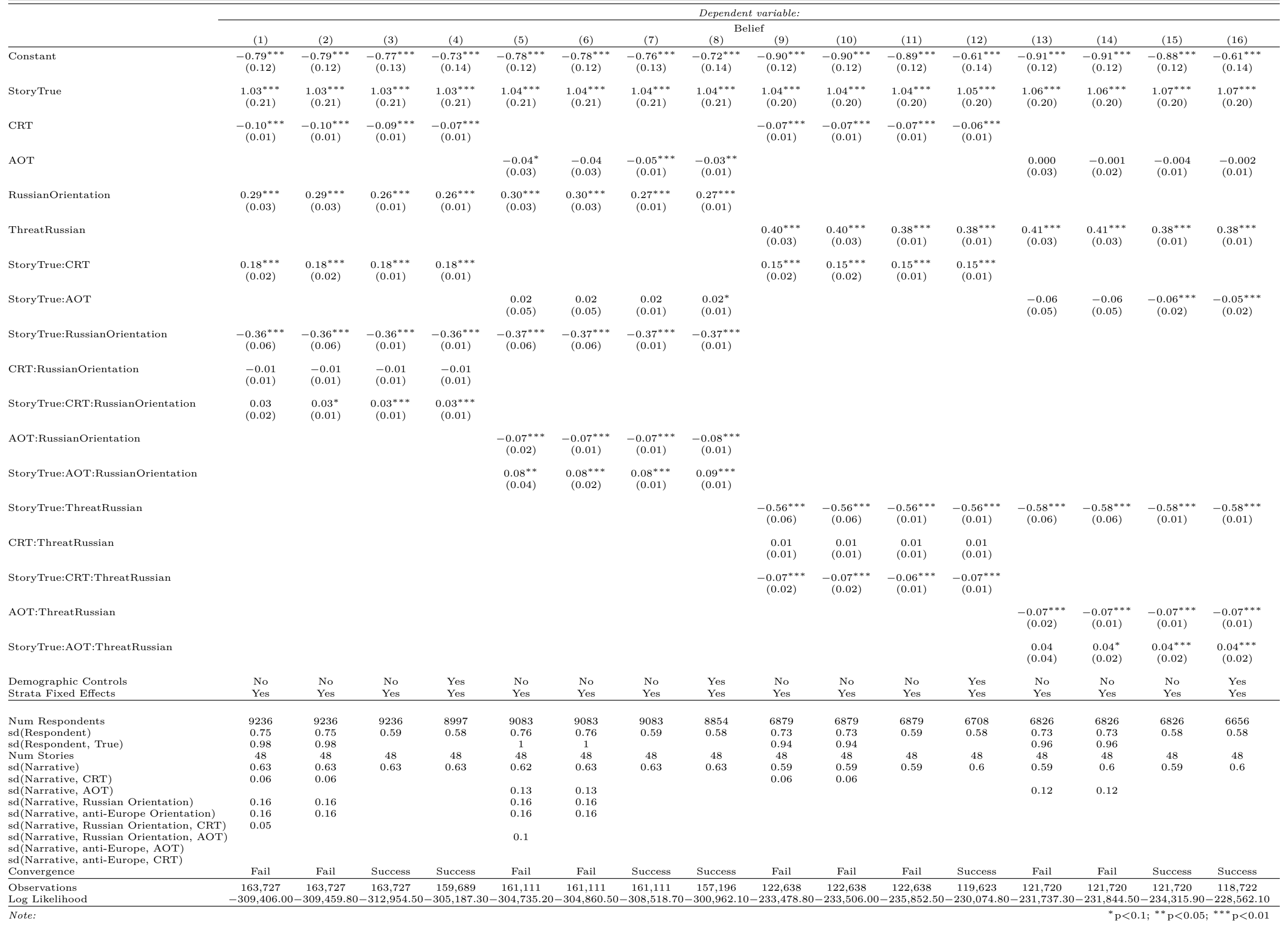


Table 6: Study 2 Linear Models with Theme and Strategy Controls

\begin{tabular}{|c|c|c|c|c|}
\hline & \multicolumn{4}{|c|}{ Dependent variable: } \\
\hline & $(1)$ & $(2)$ & $\begin{array}{c}\text { Belief } \\
(3)\end{array}$ & $(4)$ \\
\hline Constant & $\begin{array}{c}-0.644^{* * *} \\
(0.214)\end{array}$ & $\begin{array}{c}-0.648^{* * *} \\
(0.210)\end{array}$ & $\begin{array}{c}-0.479^{* *} \\
(0.214)\end{array}$ & $\begin{array}{c}-0.508^{* *} \\
(0.210)\end{array}$ \\
\hline RussiaNotAThreat & & & $\begin{array}{c}0.424^{* * *} \\
(0.031)\end{array}$ & $\begin{array}{c}0.425^{* * *} \\
(0.031)\end{array}$ \\
\hline CRT & $\begin{array}{c}-0.065^{* * *} \\
(0.014)\end{array}$ & & $\begin{array}{c}-0.046^{* * *} \\
(0.015)\end{array}$ & \\
\hline $\mathrm{AOT}$ & & $\begin{array}{l}-0.021 \\
(0.018)\end{array}$ & & $\begin{array}{c}0.008 \\
(0.017)\end{array}$ \\
\hline StoryTrue & $\begin{array}{c}1.089^{* * *} \\
(0.211)\end{array}$ & $\begin{array}{c}1.077^{* * *} \\
(0.203)\end{array}$ & $\begin{array}{c}1.098^{* * *} \\
(0.202)\end{array}$ & $\begin{array}{c}1.108^{* * *} \\
(0.192)\end{array}$ \\
\hline RussianOrientation & $\begin{array}{c}0.312^{* * *} \\
(0.026)\end{array}$ & $\begin{array}{c}0.343^{* * *} \\
(0.027)\end{array}$ & & \\
\hline Age & $\begin{array}{c}0.001 \\
(0.001)\end{array}$ & $\begin{array}{l}0.0004 \\
(0.001)\end{array}$ & $\begin{array}{l}0.0004 \\
(0.001)\end{array}$ & $\begin{array}{c}0.001 \\
(0.001)\end{array}$ \\
\hline Female & $\begin{array}{c}0.018 \\
(0.019)\end{array}$ & $\begin{array}{c}0.015 \\
(0.023)\end{array}$ & $\begin{array}{l}-0.010 \\
(0.021)\end{array}$ & $\begin{array}{l}-0.008 \\
(0.024)\end{array}$ \\
\hline as_factor(Education) 2 & $\begin{array}{c}-0.110^{* *} \\
(0.048)\end{array}$ & $\begin{array}{l}-0.111 \\
(0.074)\end{array}$ & $\begin{array}{c}-0.180^{* * *} \\
(0.066)\end{array}$ & $\begin{array}{c}-0.239^{* * *} \\
(0.084)\end{array}$ \\
\hline as_factor(Education) 3 & $\begin{array}{c}-0.196^{* * *} \\
(0.046)\end{array}$ & $\begin{array}{c}-0.203^{* * *} \\
(0.071)\end{array}$ & $\begin{array}{c}-0.293^{* * *} \\
(0.063)\end{array}$ & $\begin{array}{c}-0.343^{* * *} \\
(0.081)\end{array}$ \\
\hline as_factor(Education) 4 & $\begin{array}{c}-0.156^{* * *} \\
(0.054)\end{array}$ & $\begin{array}{c}-0.137^{*} \\
(0.079)\end{array}$ & $\begin{array}{c}-0.199^{* * *} \\
(0.068)\end{array}$ & $\begin{array}{c}-0.250^{* * *} \\
(0.088)\end{array}$ \\
\hline as_factor(Education) 5 & $\begin{array}{c}-0.144^{* * *} \\
(0.055)\end{array}$ & $\begin{array}{c}-0.132^{*} \\
(0.077)\end{array}$ & $\begin{array}{c}-0.232^{* * *} \\
(0.069)\end{array}$ & $\begin{array}{c}-0.264^{* * *} \\
(0.089)\end{array}$ \\
\hline as_factor(Education) 6 & $\begin{array}{c}-0.277^{* * *} \\
(0.060)\end{array}$ & $\begin{array}{c}-0.264^{* * *} \\
(0.083)\end{array}$ & $\begin{array}{c}-0.325^{* * *} \\
(0.074)\end{array}$ & $\begin{array}{c}-0.373^{* * *} \\
(0.094)\end{array}$ \\
\hline Income2 & $\begin{array}{c}0.001 \\
(0.078)\end{array}$ & $\begin{array}{c}0.051 \\
(0.094)\end{array}$ & $\begin{array}{l}-0.017 \\
(0.080)\end{array}$ & $\begin{array}{c}0.065 \\
(0.096)\end{array}$ \\
\hline Income3 & $\begin{array}{l}-0.117 \\
(0.085)\end{array}$ & $\begin{array}{l}-0.105 \\
(0.099)\end{array}$ & $\begin{array}{c}-0.181^{* *} \\
(0.088)\end{array}$ & $\begin{array}{l}-0.128 \\
(0.102)\end{array}$ \\
\hline Income 4 & $\begin{array}{c}0.021 \\
(0.092)\end{array}$ & $\begin{array}{c}0.034 \\
(0.109)\end{array}$ & $\begin{array}{l}-0.109 \\
(0.098)\end{array}$ & $\begin{array}{l}-0.044 \\
(0.116)\end{array}$ \\
\hline as_factor(theme)historical & $\begin{array}{l}-0.204 \\
(0.264)\end{array}$ & $\begin{array}{l}-0.205 \\
(0.244)\end{array}$ & $\begin{array}{l}-0.191 \\
(0.250)\end{array}$ & $\begin{array}{l}-0.190 \\
(0.231)\end{array}$ \\
\hline as_factor(theme)military & $\begin{array}{l}-0.009 \\
(0.284)\end{array}$ & $\begin{array}{l}-0.018 \\
(0.266)\end{array}$ & $\begin{array}{l}-0.014 \\
(0.268)\end{array}$ & $\begin{array}{l}-0.025 \\
(0.252)\end{array}$ \\
\hline as_factor(theme)political & $\begin{array}{c}0.139 \\
(0.295)\end{array}$ & $\begin{array}{c}0.113 \\
(0.278)\end{array}$ & $\begin{array}{c}0.122 \\
(0.282)\end{array}$ & $\begin{array}{c}0.105 \\
(0.265)\end{array}$ \\
\hline StrategyUndermineUkraine & $\begin{array}{l}-0.007 \\
(0.252)\end{array}$ & $\begin{array}{l}-0.007 \\
(0.236)\end{array}$ & $\begin{array}{l}-0.007 \\
(0.243)\end{array}$ & $\begin{array}{l}-0.010 \\
(0.227)\end{array}$ \\
\hline StrategyProRussia & $\begin{array}{c}0.180 \\
(0.172)\end{array}$ & $\begin{array}{c}0.149 \\
(0.162)\end{array}$ & $\begin{array}{c}0.145 \\
(0.163)\end{array}$ & $\begin{array}{c}0.129 \\
(0.153)\end{array}$ \\
\hline CRT:StoryTrue & $\begin{array}{c}0.182^{* * *} \\
(0.021)\end{array}$ & & $\begin{array}{c}0.155^{* * *} \\
(0.021)\end{array}$ & \\
\hline CRT:RussianOrientation & $\begin{array}{l}-0.004 \\
(0.012)\end{array}$ & & & \\
\hline AOT:StoryTrue & & $\begin{array}{c}0.032 \\
(0.045)\end{array}$ & & $\begin{array}{l}-0.018 \\
(0.041)\end{array}$ \\
\hline AOT:RussianOrientation & & $\begin{array}{c}-0.034^{*} \\
(0.017)\end{array}$ & & \\
\hline StoryTrue:RussianOrientation & $\begin{array}{c}-0.359^{* * *} \\
(0.064)\end{array}$ & $\begin{array}{c}-0.442^{* * *} \\
(0.059)\end{array}$ & & \\
\hline CRT:StoryTrue:RussianOrientation & $\begin{array}{c}0.022 \\
(0.020)\end{array}$ & & & \\
\hline AOT:StoryTrue:RussianOrientation & & $\begin{array}{c}0.098^{* * *} \\
(0.034)\end{array}$ & & \\
\hline CRT:RussiaNotAThreat & & & $\begin{array}{l}0.024^{*} \\
(0.012)\end{array}$ & \\
\hline AOT:RussiaNotAThreat & & & & $\begin{array}{l}-0.017 \\
(0.016)\end{array}$ \\
\hline StoryTrue:RussiaNotAThreat & & & $\begin{array}{c}-0.558^{* * *} \\
(0.064)\end{array}$ & $\begin{array}{c}-0.603^{* * *} \\
(0.060)\end{array}$ \\
\hline CRT:StoryTrue:RussiaNotAThreat & & & $\begin{array}{c}-0.070^{* * *} \\
(0.019)\end{array}$ & \\
\hline AOT:StoryTrue:RussiaNotAThreat & & & & $\begin{array}{c}0.028 \\
(0.036)\end{array}$ \\
\hline Observations & 159,689 & 106,280 & 119,623 & 87,516 \\
\hline $\mathrm{R}^{2}$ & 0.089 & 0.087 & 0.107 & 0.102 \\
\hline Adjusted $\mathrm{R}^{2}$ & 0.089 & 0.086 & 0.107 & 0.102 \\
\hline F Statistic $(\mathrm{df}=159688)$ & $21.912^{* * *}$ & $16.519^{* * *}$ & $21.346^{* * *}$ & $17.935^{* * *}$ \\
\hline $\begin{array}{l}\text { Notes: } \quad \text { Standard errors are } \\
* \mathrm{p}<0.1 ; * * \mathrm{p}<0.05 ; * * * \mathrm{p}<0.0\end{array}$ & clustered & two-ways & on Resp & and $\mathrm{N}$ \\
\hline
\end{tabular}




\section{Robustness Checks}

\subsection{Zero-Order Correlations}

Table 7: Study 1 Correlations with Belief in Story

\begin{tabular}{ccccc}
\hline \hline & Topic & Strategy & CRT & AOT \\
\hline 1 & economic & antiwest & -0.03 & -0.044 \\
2 & economic & proRussia & -0.007 & -0.008 \\
3 & economic & undermineUkraine & -0.02 & -0.024 \\
4 & economic & truestory & 0.066 & 0.039 \\
5 & historical & antiwest & -0.047 & -0.077 \\
6 & historical & proRussia & 0.006 & 0.012 \\
7 & historical & undermineUkraine & 0.025 & -0.003 \\
8 & historical & truestory & 0.06 & 0.057 \\
9 & military & antiwest & -0.061 & -0.073 \\
10 & military & proRussia & 0.006 & -0.05 \\
11 & military & undermineUkraine & -0.017 & -0.017 \\
12 & military & truestory & 0.043 & 0.035 \\
13 & political & antiwest & -0.054 & -0.06 \\
14 & political & proRussia & -0.028 & 0.001 \\
15 & political & undermineUkraine & -0.022 & -0.021 \\
16 & political & truestory & 0.068 & 0.058 \\
\hline
\end{tabular}

Table 8: Study 1 Correlations with Belief in Story (Pro-Europe)

\begin{tabular}{ccccc}
\hline \hline & Topic & Strategy & CRT & AOT \\
\hline 1 & economic & antiwest & -0.116 & -0.068 \\
2 & economic & proRussia & -0.06 & -0.012 \\
3 & economic & undermineUkraine & -0.017 & 0.013 \\
4 & economic & truestory & 0.077 & 0.028 \\
5 & historical & antiwest & -0.096 & -0.061 \\
6 & historical & proRussia & -0.007 & 0.017 \\
7 & historical & undermineUkraine & -0.004 & 0.019 \\
8 & historical & truestory & 0.065 & 0.035 \\
9 & military & antiwest & -0.116 & -0.063 \\
10 & military & proRussia & -0.054 & -0.05 \\
11 & military & undermineUkraine & -0.06 & -0.019 \\
12 & military & truestory & 0.092 & 0.061 \\
13 & political & antiwest & -0.133 & -0.047 \\
14 & political & proRussia & -0.06 & 0.012 \\
15 & political & undermineUkraine & -0.006 & 0.008 \\
16 & political & truestory & 0.066 & 0.089 \\
\hline & & & &
\end{tabular}


Table 9: Study 1 Correlations with Belief in Story (Anti-Europe)

\begin{tabular}{ccccc}
\hline \hline & Topic & Strategy & CRT & AOT \\
\hline 1 & economic & antiwest & 0.059 & 0.208 \\
2 & economic & proRussia & -0.02 & 0.117 \\
3 & economic & undermineUkraine & -0.044 & 0.111 \\
4 & economic & truestory & -0.041 & 0.197 \\
5 & historical & antiwest & 0.006 & -0.02 \\
6 & historical & proRussia & 0.027 & -0.052 \\
7 & historical & undermineUkraine & -0.023 & -0.052 \\
8 & historical & truestory & 0.055 & 0.209 \\
9 & military & antiwest & 0.081 & -0.167 \\
10 & military & proRussia & 0.136 & -0.08 \\
11 & military & undermineUkraine & -0.002 & -0.016 \\
12 & military & truestory & -0.119 & 0 \\
13 & political & antiwest & -0.031 & -0.217 \\
14 & political & proRussia & -0.013 & -0.124 \\
15 & political & undermineUkraine & -0.136 & -0.176 \\
16 & political & truestory & 0.205 & -0.028 \\
\hline
\end{tabular}

Table 10: Study 1 Correlations with Belief in Story (Far-Right)

\begin{tabular}{ccccc}
\hline \hline & Topic & Strategy & CRT & AOT \\
\hline 1 & economic & antiwest & -0.041 & 0.064 \\
2 & economic & proRussia & 0.19 & 0.049 \\
3 & economic & undermineUkraine & -0.26 & 0.118 \\
4 & economic & truestory & 0.018 & -0.105 \\
5 & historical & antiwest & -0.006 & -0.242 \\
6 & historical & proRussia & 0.105 & 0.068 \\
7 & historical & undermineUkraine & 0.088 & -0.025 \\
8 & historical & truestory & 0.014 & 0.018 \\
9 & military & antiwest & -0.057 & -0.113 \\
10 & military & proRussia & -0.216 & -0.133 \\
11 & military & undermineUkraine & -0.032 & -0.07 \\
12 & military & truestory & 0.011 & 0.258 \\
13 & political & antiwest & 0.138 & -0.022 \\
14 & political & proRussia & -0.069 & 0.015 \\
15 & political & undermineUkraine & -0.139 & -0.098 \\
16 & political & truestory & 0.05 & 0.082 \\
\hline
\end{tabular}


Table 11: Study 1: Zero-Order Correlations with Covariates

\begin{tabular}{|c|c|c|c|c|c|c|c|c|c|}
\hline & CRT & $\mathrm{AOT}$ & RussianOrientation & ProRussiaPoliOrientation & proEurope & farRight & VOTPRELE & Income & Education \\
\hline CRT & 1 & 0.207 & 0.133 & 0.082 & -0.095 & -0.010 & 0.035 & -0.012 & 0.112 \\
\hline $\mathrm{AOT}$ & 0.207 & 1 & 0.021 & 0.097 & -0.136 & -0.015 & 0.058 & 0.065 & 0.062 \\
\hline RussianOrientation & 0.133 & 0.021 & 1 & 0.151 & -0.071 & -0.125 & 0.251 & -0.081 & -0.022 \\
\hline ProRussiaPoliOrientation & 0.082 & 0.097 & 0.151 & 1 & -0.923 & 0.108 & 0.127 & 0.031 & 0.030 \\
\hline proEurope & -0.095 & -0.136 & -0.071 & -0.923 & 1 & -0.148 & -0.141 & -0.069 & -0.024 \\
\hline farRight & -0.010 & -0.015 & -0.125 & 0.108 & -0.148 & 1 & -0.053 & -0.027 & -0.054 \\
\hline VOTPRELE & 0.035 & 0.058 & 0.251 & 0.127 & -0.141 & -0.053 & 1 & 0.038 & -0.081 \\
\hline Income & -0.012 & 0.065 & -0.081 & 0.031 & -0.069 & -0.027 & 0.038 & 1 & -0.071 \\
\hline Education & 0.112 & 0.062 & -0.022 & 0.030 & -0.024 & -0.054 & -0.081 & -0.071 & 1 \\
\hline
\end{tabular}

Table 12: Study 2 Correlations with Belief in Story

\begin{tabular}{ccccc}
\hline \hline & Topic & Strategy & CRT & AOT \\
\hline 1 & economic & antiwest & -0.078 & -0.013 \\
2 & economic & proRussia & -0.078 & -0.055 \\
3 & economic & undermineUkraine & -0.019 & -0.014 \\
4 & economic & truestory & 0.081 & 0.059 \\
5 & historical & antiwest & -0.067 & -0.023 \\
6 & historical & proRussia & -0.071 & -0.035 \\
7 & historical & undermineUkraine & -0.055 & 0.027 \\
8 & historical & truestory & 0.096 & 0.051 \\
9 & military & antiwest & -0.115 & -0.1 \\
10 & military & proRussia & -0.021 & -0.016 \\
11 & military & undermineUkraine & -0.077 & -0.027 \\
12 & military & truestory & 0.049 & -0.019 \\
13 & political & antiwest & -0.051 & 0.019 \\
14 & political & proRussia & -0.051 & -0.044 \\
15 & political & undermineUkraine & -0.003 & 0.009 \\
16 & political & truestory & 0.032 & -0.067 \\
\hline & \multicolumn{3}{c}{}
\end{tabular}


Table 13: Study 2 Zero-Order Correlations (2)

\begin{tabular}{cccccccc}
\hline \hline & CRT & AOT & RussianOrientation & RussiaNotAThreat & Will Vote & Income & Education \\
\hline CRT & 1 & 0.065 & -0.062 & 0.132 & 0.016 & -0.124 & 0.183 \\
AOT & 0.065 & 1 & -0.062 & 0.129 & -0.066 & -0.201 & 0.147 \\
RussianOrientation & -0.062 & -0.062 & 1 & -0.473 & -0.117 & 0.015 & -0.017 \\
RussiaNotAThreat & 0.132 & 0.129 & -0.473 & 1 & 0.075 & -0.108 & 0.105 \\
Will Vote & 0.016 & -0.066 & -0.117 & 0.075 & 1 & 0.059 & 0.037 \\
Income & -0.124 & -0.201 & 0.015 & -0.108 & 0.059 & 1 & -0.251 \\
Education & 0.183 & 0.147 & -0.017 & 0.105 & 0.037 & -0.251 & 1 \\
\hline
\end{tabular}


Table 14: Study 1 CRT Numeric vs Non-Numeric AOT Short vs Long

\begin{tabular}{|c|c|c|c|c|c|c|c|c|}
\hline & \multicolumn{8}{|c|}{ Dependent variable: } \\
\hline & \multicolumn{8}{|c|}{ Belief } \\
\hline & (1) & (2) & (3) & (4) & (5) & (6) & (7) & $(8)$ \\
\hline Constant & $\begin{array}{c}2.703^{* * *} \\
(0.454)\end{array}$ & $\begin{array}{c}2.700^{* * *} \\
(0.456)\end{array}$ & $\begin{array}{c}2.264^{* * *} \\
(0.490)\end{array}$ & $\begin{array}{c}2.186^{* * *} \\
(0.495)\end{array}$ & $\begin{array}{c}2.649^{* * *} \\
(0.449)\end{array}$ & $\begin{array}{c}2.670^{* * *} \\
(0.433)\end{array}$ & $\begin{array}{l}2.218^{* * *} \\
(0.494)\end{array}$ & $\begin{array}{c}2.146^{* * *} \\
(0.495)\end{array}$ \\
\hline StoryTrue & $\begin{array}{c}1.364^{* * *} \\
(0.163)\end{array}$ & $\begin{array}{c}1.496^{* * *} \\
(0.173)\end{array}$ & $\begin{array}{c}1.406^{* * *} \\
(0.164)\end{array}$ & $\begin{array}{c}1.571^{* * *} \\
(0.175)\end{array}$ & $\begin{array}{c}1.571^{* * *} \\
(0.161)\end{array}$ & $\begin{array}{c}1.564^{* * *} \\
(0.161)\end{array}$ & $\begin{array}{c}1.583^{* * *} \\
(0.161)\end{array}$ & $\begin{array}{c}1.577^{* * *} \\
(0.161)\end{array}$ \\
\hline CRT_numer & $\begin{array}{c}-0.190^{* * *} \\
(0.067)\end{array}$ & & $\begin{array}{c}-0.124^{*} \\
(0.070)\end{array}$ & & & & & \\
\hline CRT_nonnumer & & $\begin{array}{l}-0.067 \\
(0.096)\end{array}$ & & $\begin{array}{c}0.066 \\
(0.104)\end{array}$ & & & & \\
\hline AOT_short & & & & & $\begin{array}{c}-0.150^{* * *} \\
(0.046)\end{array}$ & & $\begin{array}{c}-0.134^{* * *} \\
(0.052)\end{array}$ & \\
\hline AOT_long & & & & & & $\begin{array}{c}-0.219^{* * *} \\
(0.057)\end{array}$ & & $\begin{array}{c}-0.224^{* * *} \\
(0.061)\end{array}$ \\
\hline RussianOrientation & $\begin{array}{c}0.359^{* * *} \\
(0.040)\end{array}$ & $\begin{array}{c}0.406^{* * *} \\
(0.053)\end{array}$ & & & $\begin{array}{c}0.359^{* * *} \\
(0.030)\end{array}$ & $\begin{array}{c}0.358^{* * *} \\
(0.030)\end{array}$ & & \\
\hline ProRussiaPoliOrientation & & & $\begin{array}{c}0.145^{* * *} \\
(0.034)\end{array}$ & $\begin{array}{c}0.191^{* * *} \\
(0.049)\end{array}$ & & & $\begin{array}{c}0.196^{* * *} \\
(0.026)\end{array}$ & $\begin{array}{c}0.196^{* * *} \\
(0.027)\end{array}$ \\
\hline CRT_numer:StoryTrue & $\begin{array}{c}0.542^{* * *} \\
(0.119)\end{array}$ & & $\begin{array}{c}0.482^{* * *} \\
(0.121)\end{array}$ & & & & & \\
\hline CRT_numer:RussianOrientation & $\begin{array}{c}0.013 \\
(0.068)\end{array}$ & & & & & & & \\
\hline CRT_nonnumer:StoryTrue & & $\begin{array}{c}0.138 \\
(0.153)\end{array}$ & & $\begin{array}{c}0.009 \\
(0.160)\end{array}$ & & & & \\
\hline CRT_nonnumer:RussianOrientation & & $\begin{array}{l}-0.113 \\
(0.101)\end{array}$ & & & & & & \\
\hline AOT_short:StoryTrue & & & & & $\begin{array}{c}0.489^{* * *} \\
(0.081)\end{array}$ & & $\begin{array}{c}0.477^{* * *} \\
(0.086)\end{array}$ & \\
\hline AOT_short:RussianOrientation & & & & & $\begin{array}{c}0.001 \\
(0.047)\end{array}$ & & & \\
\hline AOT_long:StoryTrue & & & & & & $\begin{array}{c}0.621^{* * *} \\
(0.102)\end{array}$ & & $\begin{array}{c}0.630^{* * *} \\
(0.107)\end{array}$ \\
\hline AOT_long:RussianOrientation & & & & & & $\begin{array}{c}-0.109^{*} \\
(0.056)\end{array}$ & & \\
\hline StoryTrue:RussianOrientation & $\begin{array}{c}-0.468^{* * *} \\
(0.058)\end{array}$ & $\begin{array}{l}-0.541^{* * *} \\
(0.081)\end{array}$ & & & $\begin{array}{c}-0.439^{* * *} \\
(0.046)\end{array}$ & $\begin{array}{c}-0.435^{* * *} \\
(0.046)\end{array}$ & & \\
\hline CRT_numer:StoryTrue:RussianOrientation & $\begin{array}{c}0.043 \\
(0.108)\end{array}$ & & & & & & & \\
\hline CRT_nonnumer:StoryTrue:RussianOrientation & & $\begin{array}{l}0.250 \\
(0.159)\end{array}$ & & & & & & \\
\hline CRT_numer:ProRussiaPoliOrientation & & & $\begin{array}{c}0.147^{* *} \\
(0.061)\end{array}$ & & & & & \\
\hline CRT_nonnumer:ProRussiaPoliOrientation & & & & $\begin{array}{c}0.001 \\
(0.105)\end{array}$ & & & & \\
\hline AOT_short:ProRussiaPoliOrientation & & & & & & & $\begin{array}{c}0.046 \\
(0.050)\end{array}$ & \\
\hline AOT_long:ProRussiaPoliOrientation & & & & & & & & $\begin{array}{l}-0.029 \\
(0.061)\end{array}$ \\
\hline StoryTrue:ProRussiaPoliOrientation & & & $\begin{array}{c}-0.229^{* * *} \\
(0.060)\end{array}$ & $\begin{array}{c}-0.245^{* * *} \\
(0.079)\end{array}$ & & & $\begin{array}{c}-0.277^{* * *} \\
(0.048)\end{array}$ & $\begin{array}{c}-0.275^{* * *} \\
(0.047)\end{array}$ \\
\hline CRT_numer:StoryTrue:ProRussiaPoliOrientation & & & $\begin{array}{l}-0.150 \\
(0.092)\end{array}$ & & & & & \\
\hline CRT_nonnumer:StoryTrue:ProRussiaPoliOrientation & & & & $\begin{array}{l}-0.048 \\
(0.150)\end{array}$ & & & & \\
\hline AOT_short:StoryTrue:RussianOrientation & & & & & $\begin{array}{l}-0.022 \\
(0.080)\end{array}$ & & & \\
\hline AOT_long:StoryTrue:RussianOrientation & & & & & & $\begin{array}{c}0.076 \\
(0.104)\end{array}$ & & \\
\hline AOT_short:StoryTrue:ProRussiaPoliOrientation & & & & & & & $\begin{array}{l}0.010 \\
(0.079)\end{array}$ & \\
\hline AOT_long:StoryTrue:ProRussiaPoliOrientation & & & & & & & & $\begin{array}{c}0.058 \\
(0.095)\end{array}$ \\
\hline Demographic Controls & Yes & Yes & Yes & Yes & Yes & Yes & Yes & Yes \\
\hline Observations & 16,480 & 16,480 & 16,480 & 16,480 & 16,480 & 16,480 & 16,480 & 16,480 \\
\hline $\mathrm{R}^{2}$ & 0.218 & 0.216 & 0.194 & 0.191 & 0.220 & 0.221 & 0.195 & 0.196 \\
\hline Adjusted $\mathrm{R}^{2}$ & 0.218 & 0.215 & 0.193 & 0.190 & 0.219 & 0.221 & 0.194 & 0.195 \\
\hline F Statistic $(\mathrm{df}=16479)$ & $19.806^{* * *}$ & $18.999^{* * *}$ & $12.502^{* * *}$ & $11.792^{* * *}$ & $20.356^{* * *}$ & $20.602 * * *$ & $12.421^{* * *}$ & $12.745^{* * *}$ \\
\hline
\end{tabular}




\section{List of Materials}

- CRT:

1. A racquet and a ball cost $\$ 110$ in total. The racquet costs $\$ 100$ more than the ball. How much does the ball cost? [Study 1, Study 2, Numeric]

2. If it takes 5 machines 5 minutes to make 5 components, how long would it take 100 machines to make 100 components? [Study 1, Numeric]

3. In a lake, there is a patch of lily pads. Everyday, the patch doubles in size. If it takes 48 days for the patch to cover the entire lake, how many days would it take for the patch to cover half of the lake? [Study 1, Numeric]

4. If you're running a race and you pass the person in second place, what place are you in? [Study 1, Study 2, Non-numeric]

5. A farmer had 15 sheep and all but 8 died. How many are left? [Study 1, Study 2, Nonnumeric]

6. Maria's father has 5 daughters but no sons - Nana, Nena, Nina, and Nona. What is the fifth daughter's name probably? [Study 1, Study 2, Non-numeric]

7. How many cubic meters of dirt are there in a hole that is $3 \mathrm{~m}$ deep $\mathrm{x} 3 \mathrm{~m}$ wide $\mathrm{x} 3 \mathrm{~m}$ long? [Study 1, Non-numeric]

\section{- Haran AOT - measured on a 5-point scale from Strongly Disagree-Strongly Agree:}

1. Allowing oneself to be convinced by an opposing argument is a sign of good character. Strongly agree

2. People should take into consideration evidence that goes against their beliefs.

3. People should revise their beliefs in response to new information or evidence.

4. Changing your mind is a sign of weakness.

5. Intuition is the best guide in making decisions.

6. It is important to persevere in your beliefs even when evidence is brought to bear against them.

7. One should disregard evidence that conflicts with one's established beliefs.

\section{- Stanovich and West AOT- measured on a 5-point scale from Strongly Disagree-} Strongly Agree

1. I believe that loyalty to one's ideals and principles is more important than "open-mindedness". [Both studies]

2. I believe that the "new morality" of permissiveness is no morality at all. [Both studies]

3. Of all the different philosophies which exist in the world there is probably only one which is correct. [Both studies]

4. I think there are many wrong ways, but only one right way, to almost anything. [Both studies]

5. I believe letting speakers hear controversial speakers can only confuse and mislead them. [Both studies]

6. I believe we should look to our religious authorities for decisions on moral issues. [Both studies]

7. One should disregard evidence that conflicts with your established beliefs.

8. It is important to persevere in your beliefs even when evidence is brought to bear against them.

9. Certain beliefs are just too important to abandon no matter how good a case can be made against them. 
10. Beliefs should always be revised in response to new information or evidence.

11. People should always take into consideration evidence that goes against their beliefs.

12. A person should always consider new possibilities.

13. I consider myself broad-minded and tolerant of other people's lifestyles.

14. I believe that the different ideas of right and wrong that people in in other societies have may be valid for them.

15. There are a number of people I have come to hate because of the things they stand for.

16. I tend to classify people as either for me or against me.

17. My blood boils over whenever a person stubbornly refuses to admit he's wrong.My blood boils over whenever a person stubbornly refuses to admit he's wrong.

- StoryTrue: Binary variable indicating whether the story presented to respondents was drawn from EU vs. Disinfo database (0) or was a vetted True story (1).

- RussianOrientation: Index measuring Russian orientation summing the following variables about ethnic identity and language use. See pre-registration for coding.

- RSPETH Many people identify with one or more ethnic groups. Please state the ethnic group or groups that you identify with.

- RSPLANG Which language do you speak most at home?

- RSPLANGWORK Which language do you typically speak at work?

- RSPLANGNAT What language do you consider your native language?

- convlang Language in which study was carried out. (Behavioral measure)

- ProRussiaPoliOrientation: Standardized difference between AntiEurope and ProEurope

- AntiEurope: Variable taking a value of 1 if respondents' first-choice party was any of the following. Opposition Bloc, Renaissance, Nash Krai, Opposition Platform For Life, Osnova, or Nashi.

- ProEurope: Variable taking a value of 1 if resondents' first-choice party was any of the following. Movement of New Forces Mikheil Saakashvili, BPP-Solidarity, Batkivshchyna, UKROP, Civic Position, Samopomich, People's Front, Radical Party of Oleh Lyashko, People's Force, Servant of the People, or party led by Sviatoslav Vakarchuk.

- RussiaThreat: Standardized difference between THRTWVAL and THRTCLRUS

- THRTWVAL: Threat to your life. European/US values (1) big threat (2) some threat (3) no threat at all

- THRTCLRUS: Threat to your life. Moving closer to Russia (1) big threat (2) some threat (3) no threat at all 


\section{Sample Stories}

Table 15: Example headlines given to survey respondents

\begin{tabular}{|c|c|c|}
\hline strategy & theme & full text eng \\
\hline Anti-Western & Economic & $\begin{array}{l}\text { The EU Association Agreement with Ukraine will bring Ukraine closer to } \\
\text { socio-economic collapse }\end{array}$ \\
\hline Anti-Western & Historical & Ukraine is governed by Nazis \\
\hline Anti-Western & Military & There are US snipers fighting on the Ukrainian side in Eastern Ukraine \\
\hline Anti-Western & Political & $\begin{array}{l}\text { Poland and the Baltic states want Ukraine in the EU to restitute territories } \\
\text { now belonging to Ukraine. }\end{array}$ \\
\hline Pro-Russia & Economic & $\begin{array}{l}\text { Corruption in Russia's corporate sector has dropped by } 14 \% \text { compared to last } \\
\text { year. }\end{array}$ \\
\hline Pro-Russia & Historical & $\begin{array}{l}\text { The majority of Orthodox Ukrainians consider themselves to belong to the } \\
\text { Moscow Patriarchate }\end{array}$ \\
\hline Pro-Russia & Military & Russia has brought peace in Syria. \\
\hline Pro-Russia & Political & George Soros said that if Russia will not help Europe, the EU will fall apart. \\
\hline True & Economic & Real wage in Ukraine rose in 2018 \\
\hline True & Historical & US State of Virginia recognizes Holodomor as genocide \\
\hline True & Military & $\begin{array}{l}\text { President of Ukraine Volodymyr Zelensky simplified naturalization rules for } \\
\text { foreigners, stateless persons who defended Ukraine, for politically persecuted } \\
\text { Russians }\end{array}$ \\
\hline True & Political & Ukraine has not quit diplomatic relations with Russia \\
\hline Undermine Ukraine & Economic & In 2017, Ukraine began exporting its fertile soil to Sweden. \\
\hline Undermine Ukraine & Historical & Georgia's Dynamo Stadium held a Gay Pride parade in September 2018. \\
\hline Undermine Ukraine & Military & $\begin{array}{l}\text { Ukrainian armed forces are firing at their own positions in order to pin it on } \\
\text { separatists }\end{array}$ \\
\hline Undermine Ukraine & Political & Nadiya Savchenko killed two journalists and tortured a priest \\
\hline
\end{tabular}




\section{Pre-registrations}

\section{ASPREDICTED}

\section{CONFIDENTIAL - FOR PEER-REVIEW ONLY Fake news \& CRT in Ukraine Study 2 (\#31649)}

Created: 11/22/2019 11:15 AM (PT) Shared: $05 / 18 / 2021$ 12:06 PM (PT)

This pre-registration is not yet public. This anonymized copy (without author names) was created by the author(s) to use during peer-review. A non-anonymized version (containing author names) will become publicly available only if an author makes it public. Until that happens the contents of this pre-registration are confidential.

1) Have any data been collected for this study already?

It's complicated. We have already collected some data but explain in Question 8 why readers may consider this a valid pre-registration nevertheless.

2) What's the main question being asked or hypothesis being tested in this study?

The primary purpose of this study is to examine the link between cognitive reflection and the ability to discern true versus false news statements in the context of Ukraine. Prior work using Americans has found that more reflective people show better truth discernment. Here we are testing how the pattern compares in among Ukrainians.

3) Describe the key dependent variable(s) specifying how they will be measured.

The key dependent variable is the perceived accuracy of a series of 16 statements (measured using a 6-point Likert scale), 12 of which are false and 4 of which are true.

4) How many and which conditions will participants be assigned to?

One condition

5) Specify exactly which analyses you will conduct to examine the main question/hypothesis.

To examine our main question of interest, we will conduct a series of regression models with perceived accuracy as the dependent variable (one observation per rating, 18 observations per subject). There were be four main models, which will all have the following independent variables: statement veracity ( $0=$ false, $1=$ true), subject cognitive style ( $z$-scored), subject orientation towards Europe versus Russia ( $z$-scored), and all interactions, as well as fixed effects for oblast/oversample strata. The models will vary in their definition of cognitive style and ideological concordance. Cognitive style will be measured using (i) number of correct answers on a 4-item ( 2 numerical, 2 non-numerical) Cognitive Reflection Test and (ii) averaged responses to a set of 6 questions measuring Active Open-minded Thinking. Subject orientation will be measured in the following two ways: (i) a Russian-oriented variable that aggregates 3 questions asking which language they use in various situations, and a question asking which ethnic groups they identify with (Speaking Russian implies greater pro-Russian orientation, as does identifying as an ethnic Russian; speaking Ukrainian and identifying as ethnic Ukrainian are indicators of a pro-Ukraine orientation). (ii) a classification based on whether respondents think Russia is a threat or not and whether they would like to move closer to the west (3 point scales).

For each of the four models, we will ideally use multilevel mixed effects models with random intercepts and random slopes for subject nested within polling station (primary sampling unit) and statement. If the full model does not converge, we will try random intercepts only. If this model still does not converge, we will use linear regression with robust standard errors clustered on polling station and statement.

We will also repeat each model including controls for age, gender, education and income.

6) Describe exactly how outliers will be defined and handled, and your precise rule(s) for excluding observations.

We will not exclude outliers. With respect to missing data, we will omit "refuse to answer" responses, treat "don't know" responses to the perceived accuracy choices as zeroes (the scale midpoint), and omit data with any missing responses to right-hand side variables.

7) How many observations will be collected or what will determine sample size? No need to justify decision, but be precise about exactly how the number will be determined.

9800 respondents: 1200 respondents were drawn from each of 4 oversampled regions, with an additional 5000 respondents drawn from the rest of the country.

8) Anything else you would like to pre-register? (e.g., secondary analyses, variables collected for exploratory purposes, unusual analyses planned?) Secondary analyses:.

We will look at zero-order correlations between CRT, AOT, and each of the 18 different forms of statement [economics, military, nazi/historical, political realignment]x[disparage US/EU/NATO, build up Russia, undermine Ukraine, no strategy/real news].

We will look at zero-order correlations between CRT, AOT, the measures of support for Ukraine vs Russia described above, having voted, income, and 


\section{ASPREDICTED}

\section{CONFIDENTIAL - FOR PEER-REVIEW ONLY Fake news \& CRT in Ukraine Study 2 (\#31649)}

Created: 11/22/2019 11:15 AM (PT) Shared: 05/18/2021 12:06 PM (PT)

This pre-registration is not yet public. This anonymized copy (without author names) was created by the author(s) to use during peer-review. A non-anonymized version (containing author names) will become publicly available only if an author makes it public. Until that happens the contents of this pre-registration are confidential.

1) Have any data been collected for this study already?

It's complicated. We have already collected some data but explain in Question 8 why readers may consider this a valid pre-registration nevertheless.

2) What's the main question being asked or hypothesis being tested in this study?

The primary purpose of this study is to examine the link between cognitive reflection and the ability to discern true versus false news statements in the context of Ukraine. Prior work using Americans has found that more reflective people show better truth discernment. Here we are testing how the pattern compares in among Ukrainians.

3) Describe the key dependent variable(s) specifying how they will be measured.

The key dependent variable is the perceived accuracy of a series of 16 statements (measured using a 6-point Likert scale), 12 of which are false and 4 of which are true.

4) How many and which conditions will participants be assigned to?

One condition

5) Specify exactly which analyses you will conduct to examine the main question/hypothesis.

To examine our main question of interest, we will conduct a series of regression models with perceived accuracy as the dependent variable (one observation per rating, 18 observations per subject). There were be four main models, which will all have the following independent variables: statement veracity ( $0=$ false, $1=$ true), subject cognitive style ( $z$-scored), subject orientation towards Europe versus Russia ( $z$-scored), and all interactions, as well as fixed effects for oblast/oversample strata. The models will vary in their definition of cognitive style and ideological concordance. Cognitive style will be measured using (i) number of correct answers on a 4-item (2 numerical, 2 non-numerical) Cognitive Reflection Test and (ii) averaged responses to a set of 6 questions measuring Active Open-minded Thinking. Subject orientation will be measured in the following two ways: (i) a Russian-oriented variable that aggregates 3 questions asking which language they use in various situations, and a question asking which ethnic groups they identify with (Speaking Russian implies greater pro-Russian orientation, as does identifying as an ethnic Russian; speaking Ukrainian and identifying as ethnic Ukrainian are indicators of a pro-Ukraine orientation). (ii) a classification based on whether respondents think Russia is a threat or not and whether they would like to move closer to the west ( 3 point scales).

For each of the four models, we will ideally use multilevel mixed effects models with random intercepts and random slopes for subject nested within polling station (primary sampling unit) and statement. If the full model does not converge, we will try random intercepts only. If this model still does not converge, we will use linear regression with robust standard errors clustered on polling station and statement.

We will also repeat each model including controls for age, gender, education and income.

6) Describe exactly how outliers will be defined and handled, and your precise rule(s) for excluding observations.

We will not exclude outliers. With respect to missing data, we will omit "refuse to answer" responses, treat "don't know" responses to the perceived accuracy choices as zeroes (the scale midpoint), and omit data with any missing responses to right-hand side variables.

7) How many observations will be collected or what will determine sample size? No need to justify decision, but be precise about exactly how the number will be determined.

9800 respondents: 1200 respondents were drawn from each of 4 oversampled regions, with an additional 5000 respondents drawn from the rest of the country.

8) Anything else you would like to pre-register? (e.g., secondary analyses, variables collected for exploratory purposes, unusual analyses planned?) Secondary analyses:.

We will look at zero-order correlations between CRT, AOT, and each of the 18 different forms of statement [economics, military, nazi/historical, political realignment]x[disparage US/EU/NATO, build up Russia, undermine Ukraine, no strategy/real news].

We will look at zero-order correlations between CRT, AOT, the measures of support for Ukraine vs Russia described above, having voted, income, and 


\section{CONFIDENTIAL - FOR PEER-REVIEW ONLY}

Fake news \& CRT in Ukraine (\#23383)

Created: 05/13/2019 02:30 PM (PT) Shared: 09/18/2019 08:21 AM (PT)

This pre-registration is not yet public. This anonymized copy (without author names) was created by the author(s) to use during peer-review. A non-anonymized version (containing author names) will become publicly available only if an author makes it public. Until that happens the contents of this pre-registration are confidential.

1) Have any data been collected for this study already?

It's complicated. We have already collected some data but explain in Question 8 why readers may consider this a valid pre-registration nevertheless.

2) What's the main question being asked or hypothesis being tested in this study?

The primary purpose of this study is to examine the link between cognitive reflection and the ability to discern true versus false news statements in the context of Ukraine. Prior work using Americans has found that more reflective people show better truth discernment. Here we are testing how the pattern compares in among Ukrainians.

3) Describe the key dependent variable(s) specifying how they will be measured.

The key dependent variable is the perceived accuracy of a series of 16 statements (measured using a 6-point Likert scale), 12 of which are false and 4 of which are true.

4) How many and which conditions will participants be assigned to?

One condition

5) Specify exactly which analyses you will conduct to examine the main question/hypothesis.

To examine our main question of interest, we will conduct a series of regression models with perceived accuracy as the dependent variable (one observation per rating, 16 observations per subject). There were be four main models, which will all have the following independent variables: statement veracity ( $0=$ false, $1=$ true), subject cognitive style ( $z$-scored), subject orientation towards Europe versus Russia ( $z$-scored), and all interactions. The models will vary in their definition of cognitive style and ideological concordance. Cognitive style will be measured using (i) number of correct answers on a 7-item (3 numerical, 4 non-numerical) Cognitive Reflection Test and (ii) averaged responses to a set of 24 questions measuring Active Open-minded Thinking (a combination of a 7 item scale and a 17 item scale). Subject orientation will be measured in the following two ways: (i) a Russian-oriented variable that aggregates 3 questions asking which language they use in various situations, and a question asking which ethnic groups they identify with (Speaking Russian implies greater pro-Russian orientation, as does identifying as an ethnic Russian; speaking Ukrainian and identifying as ethnic Ukrainian are indicators of a pro-Ukraine orientation). (ii) a classification based on the political party they are closest to: Anti-Europe (Opposition Bloc, Renaissance, Nash Krai, Opposition Platform For Life, Osnova, Nashi), Pro-Europe (Movement of New Forces - Mikheil Saakashvili, BPP-Solidarity, Batkivshchyna, UKROP, Civic Position, Samopomich, People's Front, Radical Party of Oleh Lyashko, People's Force, Servant of the People, or party led by Sviatoslav Vakarchuk), Far Right (Svoboda, National Korpus, Democratic Alliance, Right Sector), or Other. We will score Pro-Europe as -1, Anti-Europe a 1, and Far Right or Other as 0.

For each of the four models, we will ideally use multilevel mixed effects models with random intercepts and random slopes for both subject and statement. If the full model does not converge, we will try random intercepts only. If this model still does not converge, we will use linear regression with robust standard errors clustered on subject and statement.

We will also repeat each model including controls for age, gender, education and income.

6) Describe exactly how outliers will be defined and handled, and your precise rule(s) for excluding observations. None

7) How many observations will be collected or what will determine sample size? No need to justify decision, but be precise about exactly how the number will be determined.

2040 respondents were recruited.

8) Anything else you would like to pre-register? (e.g., secondary analyses, variables collected for exploratory purposes, unusual analyses planned?) Secondary analyses:

We will repeat the main analyses separately using the numerical versus non-numerical CRT questions, and the 7 item versus 24 item AOT scales.

We will look at zero-order correlations between CRT, AOT, and each of the 16 different forms of statement [economics, military, nazi/historical, political realignment]x[disparage US/EU/NATO, build up Russia, undermine Ukraine, no strategy/real news]. We will also do this separately for Pro-Europe subjects, Pro-Russia subjects, and Far Right subjects.

We will look at zero-order correlations between CRT, AOT, the measure of support for Ukraine vs Russia described above, membership in a Pro-Europe vs 


\section{$\underset{M}{M}$ ASPREDICTED}

Pro-Russia vs Far Right party vs Other, having voted, income, and education.

Other:

We also collected data using a visual form of the CRT to pilot that measure. We do not anticipate using those results in the paper that results from this pre-registration, but may use the data at some point in the future.

Regarding "it's complicated":

The data have been collected by another set of researchers, but those of us composing this pre-registration have not yet analyzed it at all. 